\title{
İSLAM AKÂİDININ MODELLEDİĞİ SORUMLU ÖZGÜR KİŞILIKK
}

\section{Hacer Şahinalp*}

\section{$\ddot{\mathbf{O} z}$}

Her inanç sistemi, her düşünce ya da mistik akım, örnek bir kişilik tasavvuruyla tarih sahnesine çıkar ve fikrî temellerini bu modeller üzerinden vermeye çalışır. İslam da kendi hakikat anlayışını ve onu taşıyan değerleri mü'min kişilik üzerinden takdim eder, mü' min kişiliği de bu temeller üzerinden inşa eder. Kur'ânî bildirimle en genel anlamda bu kişiden beklenen her anlamda dengeyi muhafaza ederek kulluk bilinci içinde, yeryüzünü ifsattan (fesad fi'l-arḍ) kurtarıp sslah ve ma'mûr etmesidir. İnsanın "halife" sıfatıyla üzerine aldığ 1 bu sorumlulukta kendisini motive edecek en büyük enerjiyi, özgür iradesiyle kabullenip bağlandığı ('a k d) Allah'ın varlığına ve birliğine iman altında sıralanan İslam'ın iman esaslarından alır. Bu esaslarda baskın olan unsur, insanın yapıp etmelerinin gözetlenip kayıt altına alınıyor ve bunlardan mutlaka hesaba çekilecek olmasıdır. Sorumluluk bilincinin insanî vicdanda kök salmasına yol açan bu anlayış, bir günü diğer gününe denk olmayan ve kendi nefsi de dahil her şeye Allah'ın emaneti nazarıyla bakan hassas, ölçülü ve aktif bir kişiliğin oluşmasına zemin hazırlar.

Anahtar Kelimeler: Kelâm, 'Aḳāid, İman, Hürriyet, Sorumluluk, Mü’min Kişilik RESPONSIBLE AND INDEPENDET PERSONALITY MODELLED BY 'AQAID

\begin{abstract}
Every faith system, every thought or mystical movement, appears in the stage of history with the conception of an exemplary personality and tries to offer its intellectual foundations through these models. Islam presents its own understanding of the truth and the values on which it bears, by means of a Muslim personality; and the Muslim personality is constructed on these foundations. It is the improvement and rebuilding of the earth by saving it from conspiracy (corruption on earth) within the consciousness of servanthood, by maintaining the balance in every sense that are expected from such person in a general sense by Qur'anic notifications. The largest energy to motivate oneself in this burden/responsibility undertaken with the capacity of Caliph is provided by the faith guidelines of the Islam listed under the faith in the presence and unity of the Allah to which acknowledged and committed with his/her free will (agreement). The dominant element in these guidelines is that the actions and doings of the human are monitored and recorded down and they are required to be accountable for such things.
\end{abstract}

Article Types / Makale Türü: Research Article / Araştırma Makalesi

Received / Makale Geliş Tarihi: 18.06.2019 Accepted / Kabul Tarihi:21.12.2019

Doi: $10.26791 /$ sarkiat.579536

* Dr. Öğretim Üyesi, Mardin Artuklu Ü. İslâmî İlimler Fakültesi, Kelâm ve İslâm Mezhepleri A.B.D., hacersahinalp@artuklu.edu.tr

ORCID ID: 0000-0002-9542-2606

Bu makale 26-27 Nisan 2018 yılında Kahramanmaraş’ta düzenlenen “Uluslararası İslâm ve Model İnsan Sempozyumu"nda sözlü olarak sunulan ve basılmayan "Akâidin Modellediği Sorumluluğunu Yüklenen Özgür Kişilik” adlı tebliğin içeriği geliştirilerek ve değiştirilerek üretilmiş halidir. 
Such understanding which leads to an awareness of responsibility to be rooted in the human conscience, paves the way for the formation of a sensitive, moderate and active personality who differs from one day to other; and sees everything including his own desire in such a perspective that they were entrusted by the God.

Keywords: Kalam, 'Aqāid (Doctrines of Religious Faith), Faith, Independence, Responsibility, Muslim Personality

\section{GİRIŞ}

Allah insanı mümkün dünyalar içerisinde aktif bir özne olarak (halife) görevlendirmiş ve bunu emaneti yüklenmek olarak nitelendirmiştir. İnsana düşen, kendi kişiliğini bir takım değerler üzerinde inşâ ettikten sonra, dengeyi ve düzeni bozmadan dünyayı imar etmesi, ahlâkî temellere dayalı toplumsal yapıyı kurarak vasat/örnek toplumu gerçekleştirmesidir. Burası, hakikatin peşinden koşan insanın, kendi potansiyellerini mümkün olduğu kadar aktüel hale getireceği, hiçbir engele takılmadan sözünü söyleyebileceği ya da işini yapabileceği ma'mûr/medenî bir mekândır, eman ve emniyet yurdudur. Bir nevi, can, mal, akıl, din ve ırz/namus gibi insanın beş temel hakkının güvenceye alınıp özgürce bunların gereklerini yerine getirdiği ortamın adıdır.

Kur'ân beşerin önüne, önce inanan sonra da bu inancını amele dönüştüren insanı bir model olarak koyar. Biri olmadan diğerinin anlamını yitireceği bu denklemde iman, zihnen, ruhen ve kalben inanılması gereken değerler dizgesini ifade ederken salih amel, bunların pratiğe dönüştürülmesinin adıdır. Kalbî eylemler olarak da nitelendirebilecek iman kavramının içine, aklî faaliyet/bilgi, irade, inanç, takva, zikir, tevazu, tevekkül, sevgi, sabır, ihlas, tövbe gibi değerler dâhil edilebilir. Salih amel ise içinde fesat olmayan, insana zarar verme niyeti bulunmayan, hakikat bilgisine uygun, Allah'a itaatle ilişskili insana yararlı eylemler bütünü olarak tanımlanabilir. "Bir inanç ancak kültürleştiğinde idrak edilebilir" hale geliyorsa iman da tezahürleriyle yani pratiğe dönüştügünde insanlık için bir anlam ifade edecektir. Kişiyi eyleme yönlendirecek en önemli güçlerden biri, imanından alacağı enerjidir. ${ }^{1}$ İman ise Allah'la kurulan bir 'akd'dir, bir ahidleşmedir; her akid/ahid ise sorumluluk gerektirir. ${ }^{2}$ Bunun içindir ki Kur'ân mükerreren iman edenler ve salih amel işleyenleri bir model olarak takdim etmiştir. Her ikisinin de değerli görülmesinin arkasında yatan etken, özgür bir tercihin ürünü olmalarıdır.

Bu çalışmada "akîde" kavramıyla iman, özellikle de Ehl-i Sünnet akidesi olarak kavramsallaşmış iman esasları kast edilmiş, genel çerçeve de bu şekilde oluşturulmuştur. Önemine binaen yer yer Mu'tezile'nin Beş Esası'ndan tevhid, adalet, emr-i bi'l-ma'rûf nehy-i ani'l-münker esaslarına değinilmiştir. Bunun dışında kalan farklı inanç/akîde türleri ve konuya yaklaşımlar, makalenin sınırları dikkate alınarak çalışmanın dışında tutulmuştur. Her ne kadar başlıklandırmalarda klasik yöntem takip edildiyse de başlıklar altında konunun ele alınış tarzıyla, iman esaslarına farklı bir perspektif kazandırmak amaçlanmıştır. Nitekim Kelâm literatürü, iman esaslarını gerek müstakil gerekse toplu bir şekilde konu edinen zengin bir külliyattan oluşmaktadır. Bu eserlerde mezhepsel farklılıklar da dikkate alınarak çeşitli yönlerden tartışılan bu esasları, hürriyet ve sorumluluk merkezli kişilik oluşumuna katkısı yönüyle

\footnotetext{
${ }^{1}$ Benzeri bir anlamı ifade etmek üzere bk. "Gevşemeyin, üzüntüye kapılmayın. Eğer inanmışsanız, üstün gelecek olan sizsiniz.” (Âl-i İmrân 3/139)

2 el-İsrâ $17 / 34$.
} 
değerlendiren müstakil bir çalışmaya rastlamadığımızı; dolayısıyla konunun bu yönüyle özgün olduğunu belirtmek gerekir.

Klasik bir konunun farklı bir başlık, bakış açısı ve problematikle yeniden ele alınmış olması, istifade edilen kaynakların da hem klasiklerden hem de modern çalışmalardan seçilmesini zorunlu kılmıştır. Genel olarak klasik kaynaklar temel kavramlar ve etrafındaki tartışmalar noktasında yardımcı olurken, iman esaslarıyla özgürlük ve sorumluluk ilişkisinin kurulmasında ve söz konusu kavramların anlam çerçevesini oluştumada modern kaynaklara müracaat edilmiştir.

Makale, İslâm akâidinin aklı öteleyen ya da örten dogmatik bir maddeler yığınından ibaret olmadığı, özünde ve esasında "sorumluluk yüklenen özgür kişilikler"den oluşmuş ahlâkî bir toplum kurmaya yönelik ilkeler manzumesi olduğunu ispatlamaya yöneliktir. Kavramların tam olarak anlaşılabilmesi ve aradaki bağlantıların sağlam bir şekilde kurulması için ana konuya bir geçiş mesabesinde olmak üzere iman-özgürlüksorumluluk arasındaki sıkı ilişki, söz konusu kavramların anlam içeriklerinden hareketle açıklanmaya çalışılmıştır.

\section{1. Özgürlük (Hürriyet)}

Özgürlük (hürriyet), kendisine yüklenen pek çok anlamın yanında genel olarak zorlamanın yokluğu veya dilediğini yapan kimsenin durumu olarak tanımlanabilir. ${ }^{3}$ Özgürlüğün Arapça karşılığı olan hürriyet, bu haliyle her ne kadar Kur'ân' da yer almasa $\mathrm{da}^{4}$ anlam bakımından onun geneline sirayet etmiştir denebilir. Kur'ân'ın, akıllı ve hür zihinleri muhatab alması ve insanın gerçek şerefini ancak bu özellikleriyle kazanacağına dair vurgusu, insanoğluna niyet ve tercihlerinin ürünü olan eylemleriyle bir değer atfetmesi, insan hürriyetine verdiği değeri göstermesi açısından önemlidir.

İnsanın doğuştan sahip olduğu en tabiî haklardan biri olan özgürlük/hürriyet, bireyin maddî ve manevî yönden gelişip olgunlaşmasında, şahsiyet kazanmasında, hem bireysel hem de toplumsal huzuru yakalamasında etkin bir role sahiptir. İnsanlığın, kendini geliştirerek kurtuluşunu eline alması, kendisine bir imkân olarak verilen hürriyetini ne derece gerçekleştirilebildiğine bağlıdır. Bundan dolayıdır ki Kur'ân, öncelikli olarak bireylerden kendilerini iç yaşantı düzeyinde eğitmelerini, sonrasında içselleştirilmiş manevi değerlere sahip bireylerden oluşan ahlâkî bir toplumun gerçekleştirilmesini ister. ${ }^{5}$ Bireyin bu potansiyeli yakalayabilmesi ve aktifleştirebilmesi, özgürlügünün sağlama alınmasına bağlıdır. Ancak hür olduğunu hisseden birey, zihninde kurguladığ 1 mükemmel dünyayı gerçekliğe taşıyabilir ve böylece hem kendi bütünlüğünü, hem de toplumla bütünleşmeyi sağlama adına bir başarı elde edebilir.

Dâhili ve harici etkenlere rağmen kişiye, kendi kararlarını kendisinin vermesine imkân tanıyan özgürlük, insanın sorumlu tutulabilmesinin zorunlu şartıdır. Bundan dolayıdır ki

\footnotetext{
${ }^{3}$ Konu hakkında ayrıntılı bilgi için bk. Hacer Şahinalp, Kur'ân'da Din Hürriyeti, (Doktora Tezi, Ankara Üniversitesi, 2010), 8-19.

${ }^{4}$ Bakara Suresi 178. âyette, iki defa efendi anlamına gelen hürr kelimesi kullanılmıștır. Âl-i İmrân, 35. âyette ise İmrân'ın eşinin çocuğunu mabede adaması muherrer kelimesiyle, beş âyette de köleyi hürriyetine kavuşturma anlamında tahrîr kelimesi geçmektedir. Muhammed Fuâd b. Abdilbâkī b. Sâlih elMisrî, el- Mu'cemü'l-Müfehres li elfâzi'l-Kur'âni'l-Kerîm, " ḥrr", (Kahire: y.y., 1988) Hadis kaynaklarında da genellikle kölenin karşıtı olarak hürr kelimesine ve onun türevlerinden olan muharrer kelimesine sıkça rastlamak mümkündür. Bkz. Arent Jan Wensinck, el-Mu'cemu'l-Müfehres li-elfâzi'lhadîși'n-nebevî, "ḥrr" md.; Ayrıca bu konudaki bir hadis için bk. Ebû Dâvûd, "İmâre", 14.

${ }^{5}$ Bk. Yurdagül Mehmedoğlu, "0-6 Yaş Çocuğunun Dini Duygu Gelişimi", Evin Okula Yakınlaşması ve Değişen Anne-Baba Rolleri, (Ankara: MEB Yayınları, 2003), 151-152.
} 
İslam, 1srarlı bir biçimde dindeki ihlas ve samimiyetin öneminden bahsederek, ${ }^{6}$ sürekli bir biçimde sevgi ve saygıdan doğan korku anlamındaki takva ile her an Allah'ın gözetlemesi ve kontrolü altında bulunulduğunun şuurunda olunması demek olan $i h s a n \imath^{7}$ dikkatlere sunar. ${ }^{8}$ Birer kalp fiili olan bu iki haslet ise baskıyla değil; ancak bilinçli bir tercihle kazanilir.

Hem seçen hem de seçilen açısından tercih konusu olan şeyi değerli kılan, onun bilinçli bir tercihin ürünü olmasıdır. Kur'ân, Yaratıcısıyla kurduğu ilişki boyutunda dahi, sonuçlarına katlanmak suretiyle insanın özgür olduğunu ve özgürlüğünü sonuna kadar kullanma hakkına sahip olduğunu pek çok ayetiyle dikkatlere sunar. ${ }^{9}$

\section{2. İnanç ve İman}

Arapça "emn" kökünden gelen ve kelime olarak güven, itimat, doğrulama, tasdik ve kanaat manalarını ihtiva eden iman; bir şeyin gerçekliği doğruluğu hakkında zihnin ve kalbin güven içinde olması, emniyette bulunması, şüphenin yerini iknanın ve sakinliğin almasıdır. ${ }^{10}$ Son tahlilde iman, tasdik sözcügüyle aynı anlama gelirken, ${ }^{11}$ imanın zıddı olan küfür ise "tekzîib" (yalanlamak, inkâr etmek) anlamlarına gelmektedir. ${ }^{12}$ Hucurât Sûresi'nin 14. ayetinde geçen "iman henüz kalplerinize girmedi" ifadesi ve benzeri ayet ${ }^{13}$ ve hadisler, ${ }^{14}$ imanın yerinin "kalp" olduğunu açıkça belirtmektedir. Kalp ise diş tesirlerden uzak olarak hükmünü icra eder, onun dış müdahalelere kapıları kapalıdır. Kalp fiillerinin subjektif/öznel karakteristiği, imanın hürriyete açık alanını oluşturur.

İman, insanın inandığı varlığa gönlüyle kuvvetli bir biçimde bağlandığı derin bir ruh haletidir ve bu alelade bir inançtan farklıdır. ${ }^{15} \mathrm{Bu}$ yönüyle iman, kalpte yer eden olumlu

\footnotetext{
${ }^{6}$ Bk. el-Bakara 2/139; en-Nisâ 4/146; eş- Şuarâ 26/89; es-Saffat 37/40, 74, 84, 128, 160, 169; Sad 38/83; ez-Zümer 39/2-3, 12,14.

${ }^{7}$ Buhârî, "İman", 37; Müslim, "İman", 1, 5, 7; Nesâî, "İman", 5, 6.

${ }^{8}$ Fuad Abdulbâkî, el-Mu'cemü'l-müfehres, (Kahire: y.y., 1988), 257, 925-928.

9 Bk. el-Bakara 2/256; el-Mâide 5/92, 99; Yûnus 10/99; en-Nahl 16/35, 82; el-Kehf 18/29; en-Nûr 24/54; Ankebût 29/18; Yasin 36/17; eş-Şûrâ 42/48; et-Tegābün 64/12; el-İnsân 76/2-3; el-Gāşiye 88/21-26.

10 İman tanımları için bkz. Ebu'l-Fadl Cemâleddîn Muhammed b. Manzûr, “emn”, Lisânu'l-'Arab, (Beyrut: y.y.,1955), 13: 21; Ebü'l-Kāsım Hüseyn b. Muhammed b. el-Mufaddal er-Râgıb el-İsfahânî, “emn”, el-Müfredât fî garîbi 'l-Ķur'ân (Mısır: Meymeniyye Matbaası, 1324), 24; Âsım Efendi, "emn”, Kāmus Tercümesi (İstanbul: Cemal Efendi Matbaası, 1305), 4: 548; Muhammed A'lâ b. Alî b. Muhammed Hâmid et-Tehânevî el-Fârûkī, "emn”, Keşşâfü ıștılâhâti’l-fünûn ve'l- 'ulûm, thk. Ali Dehruc, Lübnan: y.y., 1996), 1: 296; Süleyman H. Bolay, Felsefi Doktrinler Sözlüğ̈̈, (İstanbul: Ötüken Yayınevi, 1981), 215; İlhami Güler, Iman Ahlâk İlişkisi, (Ankara: Ankara Okulu Yayınları, 2003), 19.

11 Ebu'l-Hasan Ali b. İsmail el-Eş'ârî, Kitâbu 'l-Lüma 'fi 'r-red àlâ Ehli'z-Zeyğ ve 'l-Bida' nşr. Richard J. Mc Carthy, (Beyrut: y.y., 1953), 75; Ebû Mansûr Muhammed b. Mahmûd Mâtürîdî, Kitâbu't-tevhîd, nşr. Fethullah Huleyf, (İstanbul: y.y., 1979), 377; Îcî, Adududdin Abdurrahman, Mevâklf, nşr. Abdurrahman Umeyra, (Beyrut: Dâru'l-Ceyl, 1997), 3: 527,533; Ebü'l-Muîn Meymûn b. Muhammed b. Muhammed b. Mu'temid en-Nesefî, Tebșıratü'l-edille fì ușûli'd-dîn, thk. Hüseyin Atay, Ş. Ali Düzgün, (Ankara: DİB Yayınları, 2004), 306-307; Ebû Muhammed Nûruddîn Ahmed b. Mahmûd b. Ebî Bekr esSâbûnî el-Buhârî, el-Bidâye fî uṣ̂uli'd-dîn (Mâtürîdiyye Akâidi), trc. Bekir Topaloğlu, (Ankara: DİB Yayınları, 2005), 87-88

12 Ebü'l-Muîn en-Nesefî, et-Temhîd fî ușîli'd-dîn, nşr. Abdulhayy Kâbil, (Kahire: Dâru's-Sekâfe, 1987), 100.

13 Bk. el-Bakara 2/139; el-Mâide 5/41, 54; en-Nahl 16/22, 106; el-Kehf 18/28; eş-Şu'arâ 26/89; elMü'min 40/35; Muhammed 47/24; el-Hucurât 49/7; Kaf 50/33, 37; el-Mücâdele 58/22.

14 Buhârî, "Tevhid", 19; Müslim, "İman", 316, 325; Tirmizî, "Kader", 7 ve Üsame b. Zeyd'in silah korkusundan iman ettiğini zannettiği bir kişiyi öldürmesine karşılık Hz. Peygamber'in "Kalbini mi yarıp baktın?!" diyerek tepki gösterdiği bir başka hadis için bk. Müslim, "İman", 158-159; Nesâî, "İman", 18; Tirmizî, "Birr", 61; Ebû Dâvûd, "Cihâd", 95; İbn Mâce, "Fiten", 1.

${ }^{15}$ Ali Fuad Başgil, "Din Hürriyeti", A. Samim Gönensay'a Armağan, (İstanbul: y.y., 1955), 231.
} 
tavırdır; dış dünyaya ve yaşantıya aksetme yolunda, Allah'a yönelik sevgi, saygı, tevazu, hayranlık, şükran, teslimiyet ve bağlanma gibi duygusal yönleri de ağır basan, ben bilincinin şekillenmesinde önem kazanan yönüyle psikolojik bir olgu olarak da değerlendirilebilir. ${ }^{16}$

Kalpte gerçekleşen ve imanı oluşturan iki aslî bir de tamamlayıcı üç unsurdan bahsetmek mümkündür. Bunlar; irade, bilgiyle temellendirilen kesin inanç ve tamamlayıc1 unsur olarak kalp fiilleridir. ${ }^{17}$ İmanın bunlardan herhangi birine indirgenmesi doğru değildir; o ancak ilk iki unsurun mevcudiyetiyle varlık sahasına çıkar, üçüncü unsurun katılımıyla da tamlığa ulaşır. Dolayısıyla ne yalnız başına iradenin ne duyguların ne de bilginin imanı meydana getirmesi mümkündür. İrade ve duyguların imanı meydana getirebilmesi için inanç konularının aklîleștirilmesi, hissiyat mantığının oluşması gerekir. ${ }^{18}$ Gönülden bağlanma, sevgi ve samimiyetten yoksun sadece bilgi temelli ya da bilgiden yoksun duygu yoğunluklu bir inanç, iman olma derecesine yükselemeyecektir. Çoğu zaman bireysel bir tercihe dayanmadığı için salih amele dönüşmesi de zorlaşacağından, son tahlilde pratik hayat açısından bir anlam da ifade etmeyecektir.

$\mathrm{Bu}$ itibarla inanç imandan farklı olup, ona imanın, üzerinde temellendiği bir unsur olarak bakmak gerekir. İnanç, "doğru veya yanlış olma ihtimali hakkında zan ya da kanaatten kaynaklanan -az veya çok- bir güven taşıyan subjektif bir duyguya dayanarak kabul veya reddetme"dir. ${ }^{19}$ Onun, yeterli bir doğrulamadan yoksun olan güven duygusuna dayandığını söylemek mümkündür. Bu güven, güçlü bir iman ya da bilgiden kaynaklanan bir bel bağlama, bir emniyet hissi olmayıp, akla, duyguya veya iradeye uygunluktan kaynaklanan objektif kesinlikten ziyade subjektifliği ifade eden bir duygudur. ${ }^{20}$ İnancın oluşmasında zeka/akıl/zihnin yönlendirdiği bir iradeden ziyade affectif âmiller denen eğilimler, arzular ve hislerin etkinliği söz konusudur. ${ }^{21}$ İnancin imana evrilebilmesi için yukarıda da ifade ettiğimiz gibi var olan duygusal boyuta irade ve aklın eşlik etmesi gerekir. ${ }^{22}$

İmanı dinî ve aklî delillerle kuvvetlendirmek gerektiğine dair yaklaşım İslam Kelâmcılarının genel tutumu olmuştur. Taklîdî iman her ne kadar başlangıç itibariyle ve belli bir azınlık için makbul görülmüşse de, zaman içinde imanını aklî ve naklî delillerle kuvvetlendirme yoluna gitmeyenlerin bundan sorumlu olacağ zorunluluk imanın ihtiyarî boyutunu ortadan kaldırmaz. Çünkü dolaysız bir biçimde tecrübe edilemeyen, gözlemlenemeyen olgulardan olan imanî önermeler, (Allah'a iman, meleklerine iman, kitaplarına iman, ...) bilinmesi/anlaşılması zorunlu olan mantıksal ispatlarla değil, ancak olgudan ${ }^{24}$ hareket eden kanitlarla (istidlâlî/nazarî bilgi) ${ }^{25}$

\footnotetext{
${ }^{16}$ Osman Pazarlı, Din Psikoloji, (İstanbul: Remzi Kitabevi, 1982), 25.

${ }^{17} \mathrm{Bu}$ kategorilendirme için bkz. İlhami Güler, "İman ve İnkârın Ahlâkî ve Bilişsel (Kognitif) Temelleri", İslâmiyât 1/1, (Ocak-Mart 1998): 12-13.

${ }^{18}$ Pazarl, Din Psikolojisi, 19-22.

19 Hanifi Özcan, Epistemolojik Açıdan İman, (İstanbul: İfav Yayınları, 1997), 58; Krş. M. Nail Karakuşçu, Genel Psikoloji ve Normal Davranışlar, (Ankara: Çelik Yayınları, 1988), 330.

${ }^{20}$ Özcan, Epistemolojik Açıdan İman, 58.

${ }^{21}$ Nurettin Topçu, Ruhbilim, (İstanbul: Üçler Basımevi, 1949), 72-73, 76-77.

${ }^{22}$ Konu hakkında geniş bilgi için bkz. Şahinalp, Kur'an'da Din Hürriyeti, 24-26.

${ }^{23}$ Nûruddîn es-Sâbûnî, el-Bidâye fî ușûuli'd-dîn, 181 .

${ }^{24}$ Olgu kavramı iki farklı manaya gelir: Bunlardan birincisi, içe bakış ve doğrudan duyu verilerinin oluşturduğu, doğrudan deneyime dayandığından a priori bilgiler gibi zorunluluk ifade eden bilgi; ikincisi ise, duyu verilerince doğrudan verilen bilgilerin ötesine geçen ve ancak bir akıl yürütmeyle elde edilen ve zorlayıcılığı olmayan, makul bir insanın inanabilmesi için aklî şüphe zeminini ortadan kaldıran bilgi
} 
doğrulanır. Dolayısıyla, objesi gereği, bilgide insan tasdike zorlanırken, imanda işin içerisine irade karışmaktadır. İmanda doğru inanç, bilgide doğrulanmış doğru inanç kesinliği vardır. $\mathrm{Bu}$ durum, kanıtlanan şeyi tasdik etme zorunluluğuyla yüz yüze bırakmayacağı kişiye, başka türlü de inanabilme imkânı veren bir özgürlük alanı bırakmaktadır. Böylece, tüm bilgilerimizi zorunlu mantıksal doğruluklar olarak gören, dolayısıyla da bilmenin özgürlüğü yok edeceği varsayımını dillendirenlerin tezleri de geçerliliğini yitirecektir.

\section{3. İman Esasları, Özgürlük ve Sorumluluk}

İman ya da İnanç Esasları olarak Türkçe'ye geçen 'Akāid kelimesi, 'aḳd kelimesinden türetilmiş olan 'aḳide kelimesinin çoğuludur. 'Aḳd, bir şeyi diğerine sağlamca tutturmak, bağlamak, düğümlemek anlamlarına gelir. Aynı kökten türetilen i`tikăd kelimesi ise bir şeye gönül bağlamak, düğüm atmışçasına inanmak, gönülden benimsemek demektir. $\mathrm{Bu}$ durumda 'aḳide kelimesi gönülden bağlanılan, düğüm atmışçasına inanılan şeydir. ${ }^{26} \mathrm{Bu}$ yönüyle akîdeyi, genel bir sanı olarak akıl, irade ve kalbi devre dışı bırakan Müslüman'ın kör noktası olarak değil, aksine onları önce birbirine sonra da Yaratıcı'ya sıkı bir şekilde bağlayan, bağladıkça etkinliklerini arttıran sağlam bir düğüm şeklinde değerlendirmek daha isabetli olacaktır. Allah'la insan arasında kurulan bu sağlam bağı ${ }^{27}$ gönüllülük esasına dayanması, samimiyet ve ihlasın önemine işaret ettiği gibi, bunu sağlayan en önemli unsura; insana tanınan özgürlüğe de dikkatleri çeker. 'Aḳīe bu çift yönlü karakteriyle kişiyi, imanından aldığı güçle salih amel işlemeye yöneltir, onun hayatına da ölümüne de değer yükleyerek anlamlı hale getirir.

İnsanı bir yönüyle Allah dışındaki varlıklara kulluk etmekten kurtarıp özgürleştiren, diğer yönüyle de Allah karşısında sorumlu bir varlık haline getiren 'aḳīe, ulûhiyet, risalet ve ahiret şeklinde özetleyeceğimiz İslam Dini'nin kurucu kavramlarını içerir. İslam'ın inanılması gereken temel inanç esaslarını konu edinen ilmin de adı olan İslam 'Akāidi'nin konusu, Kur'ân ayetleri ve sahih haberlerle sabit olmuş itikat/iman esaslarıdır. İman esaslarının hedefinde ise özgür ve sorumlu bireyin inşası bulunur.

\subsection{Tevhid Merkezli Allah’a İman İlkesi ve Sorumlu Özgür Kişilik}

Allah'a imanı, Allah'ın sıfatlarıyla birlikte var ve bir olduğuna (Tevhid) inanmak olarak tarif eden Kelâm bilginleri, enfüs/fitrat ve âfaktaki delillerden ${ }^{28}$ hareketle Allah hakkında bilgiye ulaşmanın (marifetullah) insanın ilk ve en önemli sorumluluğu (vâcib) olduğu konusunda fikir birliği içindedir (icma). Buna göre marifetullah, insanın seçme hürriyetini ortadan kaldıran zorunlu bir bilgi olmayıp, istidlal ve nazara dayanan kesbî bir bilgidir. Bilginin kendisi zorunlu olmamakla beraber bu bilgiye akıl yürütmek (istidlal ve nazar) yoluyla ulaşmak zorunludur (vâcib). ${ }^{29}$ Bu zorunluluğun (vücûbiyetin)

anlamındadır. Bkz. Ahmet Cevizci, "Olgu", Paradigma Felsefe Sözlüğü (İstanbul: Paradipma Yayınevi, 1999), 640-641.

25 Sa'düddîn Mes'ûd b. Fahriddîn Ömer b. Burhâniddîn Abdillâh el-Herevî el-Horâsânî et-Teftâzânî, Şerḥu'l-Maķāṣıd (İstanbul: 1305), 2: 44-45; Hanifi Özcan, Mâtûrîdî'de Dinî Çoğulculuk (İstanbul: Marmara Ü. İlahiyat F. Vakfi, 1995), 78-81.

${ }^{26}$ Âsım Efendi, “'aḳd”, Kāmus Tercümesi, 1: 1212-1215; Ahmet Saim Kılavuz, “Akaid”, Türkiye Diyanet Vakfi İslâm Ansiklopedisi, (Ankara: TDV Yayınları, 1989), 2: 212-216.

27 “Allah’ın ipine topluca yapışın, ayrılığa düşmeyin.” (Âl-i İmrân 3/103)

${ }^{28}$ Bkz. Fussilet 41/53.

29 Cürcânî, bu vacipliğin mârifetullah konusunda nazardan başka yol bilmeyenler için söz konusu olacağını, dolayısıyla nazar dışında başka yollarla (keşf, ilham, nefis tezkiyesi, eğitim vs.) bu bilgiye ulaşanlara nazarın vacip olmadığını belirtir. Bk. Seyyid eş-Şerîf Ali b. Muhammed el-Cürcânî, Şerhü’l- 
kaynağı, yani akıl yürütmenin zorunluluğunun akla mı yoksa nassa mı dayandığ konusunda ise Kelâm bilginleri ihtilaf etmiş; Mu'tezile aklı, Eş'arîler ise vahyi vacip kılıcı olarak işaret ederken, Ebû Hanife ve İmam Mâtürîdî başta olmak üzere Mâtürîdî bilginlerin çoğunluğu Mu'tezile'ye, Buhâra Ekolü'ne mensup diğer bir kısmı ise Eş'arîler'e katılmıştır. ${ }^{30}$ Kelâm bilginlerinin tamamı, Allah'ın varlığı, birliği ve ezelî sıfatlara sahip olduğu, evrenin yaratılmışlı̆̆ı, peygamber göndermenin imkânı ve insanın sorumlu oluşu gibi konuların tespitinde vahiy olmaksızın aklın başlı başına bir yetkinliğe sahip olduğu kanaatindedir. ${ }^{31}$ Ancak burada söz konusu edilen durağan, salt bir akıl değil, nazar ve istidlalde bulunan işlevsel, aktif bir akıldır. ${ }^{32}$ Bundan dolayıdır ki Kelâm bilginleri, istidlal ve nazar sonucu hür bir seçimle gerçekleşecek imana değer atfetmiş, bunu mü'minin en büyük sorumluluğu olarak niteleyip, istidlal ve nazarı terk eden mukallidin günahkâr olduğu noktasında görüş birliği içinde olmuştur. ${ }^{33}$

Allah'ın varlığını ve birliğini (tevhid) kemal sıfatlarıyla birlikte bilme şeklinde özetleyebileceğimiz marifetullahın bu üç temel vasfı özgür ve sorumlu kişiliğin inşasında merkezî bir rol üstlenmektedir. Zamandan ve mekândan münezzeh olmakla birlikte kullarının dualarını işitip cevap verecek kadar, ${ }^{34}$ hatta onlara şah damarından bile daha yakın olan, ${ }^{35}$ işiten, gören, her şeyden haberdar latîf bir yaratıcının varlığına iman, âlemle aktif ilişki içinde olan bir Tanrı ve bu ilişkiye cevap veren bir âlem tasavvuru sunar. Akla aşırı bir güç ve yetki vererek hedefinden saptıran, Allah'ın evrene müdahalesini O'nun acizliği olarak yorumlayan deist düşüncenin aksine Kur’ân,

Mevâkıf, (Beyrut: Dârü'l-Kütübi'l-'İlmiyye, 1419/1998), 1: 265. Ayrıca bkz. Mehmet Şaşa, Kelam ve Tasavvuf Açısından Marifetullah, (Ankara: Nobel Yayınları, 2018), 146-159.

${ }^{30}$ Geniş bilgi için bk. Ebû Mansûr Abdülkāhir b. Tâhir et-Temimî el-Bağdadî, el-Fark beyne'l-firak, nşr. M. Abdülhamid, (Beyrut: y.y., 1416/1995), 26; Abdüllatîf Harputî, Tenkîhu'l-kelâm fî 'akâidi ehli'lİslâm, (İstanbul: Marmara Ü. İlahiyat F. Kütüphanesi, Necmu İstikbal Matbaas1, 1327), 22; İsmail Hakk1 İzmirli, Yeni İlmi Kelam, haz. Sabri Hizmetli, (Ankara: Umran Yayınları, 1981), 165. Ayrıca bk. Mahmut Ay, "Kelam'da Akıl İman İlişkisi: Temel Teolojik Yaklaşımlar”, Ankara Ü. İlahiyat Fakültesi Dergisi 52/1 (2011): 55 vd; Mehmet Şaşa, "Kelâm Ekolleri Bağlamında Marifetullah'ın Vücûbiyet Kaynağı”, Artuklu Akademi 5/1, (Haziran 2018): 57-90.

31 Bk. Abdülkāhir el-Bağdâdî, Usûlü'd-dîn, (İstanbul: y.y., 1346/1928), 25, 210; Mâtürîdî, Kitabu'tTevhid, trcm. Bekir Topaloğlu, (Ankara: Türkiye Diyanet Vakfı Yayınları, 2002), 492-496. vd.; 123129.;222-223; Mâtürîdî, Te 'vîlâtü̉'l-Kur'ân, ilmî Kontrol: Bekir Topaloğlu, (17 cilt), (İstanbul: Mizan Yayınevi, 2005-2010), 2: 262; 9: 203; 10: 293. Ebû Hâmid Muhammed b. Muhammed el-Gazzâlî, İtikad'da Orta Yol, trc. Kemal Işık, (Ankara: Ankara Üniversitesi İlahiyat Fakültesi Yayınları, 1971), 157; Cürcânî, Şerhü'l-Mevâkıf, 1: 260, 276. Marifetullah konusunu "tevhid" ilkesi, Allah'1 bilmeye götüren nazar ve istidlali ise "adalet" prensibi altında ele alan Mu'tezile, bütün sistemleri boyunca bu kavramlara yaptıkları vurgudan dolayı Ehl-i Tevhîd ve'l-'Adl olarak anılmıştır. Onlara göre tevhid ve adalet ile ilgili konular aklın etkinlik alanı içindedir ve buralarda yalnızca aklın hükümleri geçerlidir. Naklîn kendisi de akılla tespit edilmeye ihtiyaç duyduğundan bu alanda kullanılması doğru olmaz. Bkz. Ebü'l-Hasen Kādı'l-kudât b. Ahmed b. Abdilcebbâr el-Hemedânî, Şerḥu'l-Ușûli'l-ḥamse, thk. Abdülkerîm Osman, 3. Baskı. (Kahire: Mektebetü vehbe, 1416/1996), 7-8, 10, 41-45, 50-67, 128-134.

32 İşlevsel akıl hakkında bilgi için bkz. Ramazan Altıntaş, İslam Düşüncesinde İşlevsel Akıl, (İstanbul: Pinar Yayınları, 2003), 37, 75 vd.

33 Mukallidin imanı hakkında geniş bilgi için bk. Abdülkāhir el-Bağdâdî, Usûlü'd-dîn nşr. Ahmed Şemsuddîn, (Beyrut: Dâr'ül-Kütübi'l-'İlmiyye, 1423/2002), 280 vd; Nesefî, Tebșıratü'l-edille fì uṣ̂uli'ddîn, thk. Hüseyin Atay, Ş. Ali Düzgün, (Ankara: DİB Yayınları, 2004), 1: 28 vd.; Ebû Muhammed Alî b. Ahmed b. Hazm el-Endelüsî. el-Faṣl fi'l-milel ve'l-ehvâ' ve'n-nihal, nşr. Muhammed İbrâhim NasrAbdurrahmân Umeyre, (Beyrut: Dârü'l-Cîl, ts), 4: 66.

34 Bk. el-Bakara 2/186. Krş. “Doğu da batı da Allah'ındır. Nereye dönerseniz işte Allah'ın yüzü oradadır." (el-Bakara 2/115)

35 "And olsun ki insanı biz yarattık; nefsinin kendisine fısıldadıklarını biliriz ve biz ona şah damarından daha yakınız.” (Kaf 50/16) 
$\overline{\text { Allah'ın her an evrene müdahil olduğunu haber verir. }{ }^{36} \text { Peygamberler vasıtasıyla vahyini }}$ göndermesi de bu ilişki çeşitlerinden biridir.

Allah'ın varlık âlemiyle ilişkili sıfatları, bir yandan Allah hakkında belli bir tasavvurun oluşmasına katkı sunarken diğer yandan özgürlüğüyle diğer varlıklardan farklı kılınan insanı sorumluluklarına davet etmektedir. $\mathrm{Bu}$, kullarını her daim kontrol altında tutan (Kayyûm, Raḳīb, Mirșâd) ${ }^{37}$ bir Yaratıcı'yla bu bilinçle yaşamını şekillendirmekle mükellef tutulan kulun karşılıklı ilişkisidir. "Kur'ân bu sıfatları zihinlere yerleştirirken, onların sadece nazarî bakımdan kabul edilmelerini hedef tutmamış, bu sıfatların insanın hayatına te'sirine de önem vermiştir. Bunun neticesi şudur: İnsanın gizli ve âşikâr olan hayatı Allah'ın ilminin kontrolü ve murakabesi (Raḳīb) altındadır." ${ }^{38}$ Allah ya Cemâl (Raḥman, Rahîm, 'Alîm, ...) ya da Celâl (Kahhâr, Cebbâr, Şedîdu'l-'Íkâb, ...) ifade eden mükemmel sıfatlarıyla kullarını koruyup gözetlemektedir. Özellikle vahdaniyet, ilim (Semi', Bașir, Habîr,) irâde, kudret ve adalet gibi sıfatlar, bu murakabeyi güçlü bir şekilde gözler önüne sermekte, gözlemlenen şeylerin nisyanla malul olan beşerin önüne yeniden konulmak üzere kayıt altına alındığını dikkatlere sunmaktadır. Kur'ân bunu kitab (Kitâb-1 Mübîn, İmâm-1 Mübîn, Levh-i Mahfûz) ${ }^{39}$ kavramıyla ifade etmiştir. Kayıt altına alınma, zamanı geldiğinde bir hesap sorulabilirliği; bu da sorumluluğu beraberinde getirir. Dışsal bir murakabe ve hesap verme zorunluluğunun içsel bir murakabeyi doğurması beklenir. İnsanın topyekûn varlığıyla her an Allah'la yüzleşmekte olduğuna dikkat çekilmesi, onların toplum içinde ahlâkî bir yüzleşmeye hazırlanmalarına zemin hazırlar. Allah'la yüzleşme tecrübesini, insanların birbirleriyle ahlâken yüzleşmesine dönüştürmesiyle tevhid inancı bir sosyo-politik gerçeklik haline gelebilir. ${ }^{40}$

Allah'ın her bir güzel ismi ve her bir sıfatı, inanan için, kişiliğini dayandıracağı esasları ve ulaşacağı hedefleri göstermesi bakımından da oldukça önemlidir. İslam'ın insanın önüne koyduğu esas hedefin de bu olduğunu; yani "ilâhî olanın niteliklerine insanî seviyede sahip olmak" olduğunu söylemek mümkündür. Kur'ân bunu "Allah'ın ahlâkıyla ahlâklanma" olarak da açıklayabileceğimiz "sıbğatullah" kavramıyla ifade eder. ${ }^{41}$ Sınırlı düzeyde de olsa her bir ilahî sıfat/isim, mü'min için, şahsiyetini oluşturmada ve geliştirmede bir örneklik, bir sembol hüviyetindedir. ${ }^{42}$

Allah'a imanın bütün unsurlarının temerküz ettiği tevhidin ifade ettiği anlamlar farklı kategorilerde değerlendirilmiştir. Bunlardan en yaygını, Allah'ın yüce zatı ve mukaddes sıfatları yönünden bir olduğunu, ne zatında ve ne de sıfatında eşi ve benzeri bulunmadığını ifade eden Tevhid-i Uluhhiyyet ve Allah'ı amelî olarak birlemeyi, yani; bir

\footnotetext{
36 “Göklerde ve yerde bulunanlar O’ndan isterler; O her an yeni bir tasarruftadır." (er-Rahmân 55/29).

37 “Şüphesiz Rabbin gözetlemededir” (el-Fecr 89/14).

${ }^{38}$ Hüseyin Atay, Kur'an'da Iman Esaslart ve Kader Sorunu, (Ankara: Pozitif Matbaacılık, 2009), 77.

${ }^{39}$ Bk. Yûnus 10/ 61; Hûd 11/6; Tâhâ 20/52; en-Neml 27/75; Yâsîn 36/12; el-İnşikâk 84/7-12; el-Burûc $85 / 22$.

${ }^{40}$ Bk. Burhanettin Tatar, "İki Temel Kavram: Tevhid ve Vahdet", Hz. Peygamber, Tevhid ve Vahdet, (Ankara: DİB Yayınları, 2016), 18.

${ }^{41}$ Bk. Şaban Ali Düzgün, Din Birey ve Toplum, (Ankara: Akçă̆ Yayınları, 1997), 31.

42 İsimlendirmenin asıl olarak insana ait olduğu ve sözcüklerin ilk olarak beşeri düzlemde ve insana ait bir fiile atıfta bulunmak üzere üretildiği savından hareketle, Allah ve Rahman haricindeki isimlerin Allah'tan ziyade esas olarak halife makamındaki insanın model almak üzere ürettiği isimler olduğuna yönelik bir açıklama için bk. Erkan Yar, “Allah'ın İsimlerinin İnsanın Kişilik Gelişimine Etkisi”, Uluslararası Kişilik ve Karakter İnsâsında Dinin Yeri Sempozyumu Bildirileri (Ordu, 10-12 Haziran 2016), ed. Y. Ünal, ş. Pekdemir, Y. B. Gündoğdu, O. İyibilgin, S. Kar (Ordu: Ordu İlahiyat VakfiY., ts.), 165, 167-169, 171, $176,181$.
} 
tek Allah'a ihlas ve muhabbetle ibadet etmeyi, yalnız O'na iltica ederek, yalnız O'ndan yardım dilemeyi ve O'na ibadette hiçbir şeyi şerîk koşmamayı ifade eden Tevhid-i Rubûbiyyet şeklindeki ikili tasniftir. ${ }^{43} \mathrm{Bu}$ tevhid çeşidinin esasını, kişinin kalbiyle Allah'1 sevmesi, davranışlarıyla bu sevgisini ispat etmesi, yani hassas bir sorumluluk ahlâkına sahip olması oluşturur. Ulûhiyyette tevhidin insanda fikir hürriyetine, ibadette tevhidin ise duygu hürriyetine önemli katkılar sunduğu belirtilmektedir. ${ }^{44}$

Allah'a imanın merkezî kavramı olan tevhid fikrinin insana en büyük kazanımı, birçok tanrıya inanmanın getirdiği zihin parçalanmasından, bağımlılık duygusundan ve kölelikten kişiyi kurtarmasıdır. ${ }^{45}$ Tapılanların çokluğu oranında insanın kölelik bağı kuvvetçe artacak, zaman içerisinde bu bağlardan kurtuluş gittikçe zorlaşacak ve kurgulanan dünyayla hakikat arasındaki makas da gittikçe açılacaktır. Bu sapmayı sadece dışsal faktörlere (Tabiat, tarih, toplum, vs.) değil, kişinin kendi iç dünyasına (ego/Ben) da bağlayan Kur'ân, bunu "kendi hevasını ilah edinme"46 şeklinde tanımlamıştır.

İnsanın bir tek Allah'a bağlanarak yeteneklerine ket vuran engellerden kurtulması, onun hem özgür hem de sorumlu yanını işaretler. Tevhid inancıyla kişi, potansiyellerini geliştirmenin önündeki her türlü engeli aşma güç ve kudretini kendinde bulur. Allah'tan başka ilahlar edinmek ve onlara bağlanmak/tapınmak, kişiliğin zedelenerek Allah'ın insana verdiği üstün konumun (halifelik, eşref-i mahlûkat) ve emanetin reddi ve kötüye kullanımı anlamına gelecektir. Tevhid merkezli Allah'a iman düsturu, aşıladığı sorumluluk bilinciyle inananı, varoluşsal olarak ihata eder; kişiliğini ve karakterini şekillendirir ve benliğini bu temelde yeniden inşa etme firsatı verir. Tevhîde bilgi, niyet ve eylemin birliği anlamı yüklendiğinde, muvahhidi de dilinin söylediğini, kalbi ile tasdik eden, sözleri ile tasdiki uyumlu ve eylemleri sözlerine mutabık olan yani, düşündükleriyle yaptıkları, olduğu şey ile düşündüğü arasında çelişki olmayan kişi olarak nitelemek gerekir. Tevhidin bu şekilde bir bilinç haline dönüştürülüp hayatın içine taşınması, kişiyi kainatı Allah'a dayanarak yeniden okuma ve anlama çabası içine sürükler. Böylece o, olgu ve olaylara bakışta, evreni algılayış biçimlerinde, bilim ve teknolojiden sanat ve estetiğe kadar her türlü insani çabada belirleyici bir karakter olma vasfi kazanır. ${ }^{47}$

Varlıklar âleminde görülen düzen ve gayelilik, ${ }^{48}$ Tevhid inancını destekleyen en önemli göstergelerden biridir. ${ }^{49}$ Tevhid fikriyle kişi, evrende olup biten her şeyi kanun ve

${ }^{43} \mathrm{Bu}$ tasnifi üçe ve daha fazlasına çıkaranlar da vardır. Takiyuddîn Ahmed b. Ali b. Abdilkâdir b. Muhammed el-Makrîzî, Tecrîdu't-Tevhîdi'l-Müfîd, nşr. Ahmed b. Muhammed Tâhûn, (Kahire: Mektebetu't-Turasi'l-İslâmi, 1414/1993), 10; Sadruddîn Ali İbn Muhammed İbn Ebi'l-İzz el-Hanefî, Şerhu't-Ṭahâviyye fî'l- 'akîdeti's-Selefiyye, thk. Ahmed Ali, (Kahire: Dâru'l-Hadîs, 2005), 18, 23-25; Ebû Bekr Muhammed ez-Zekeriyyâ, eş-Şirk fi'l kadîm ve'l- hadîs, (Riyad: Mektebetü'r-Rüşd, 2005), 26; Mevlüt Özler, "Tevhid", 19; Ali Arslan Aydın, "Peygamberimiz, İman Esasları ve Tevhid Akidesi", Diyanet Dergisi Özel Sayl, (Ankara: y.y., 1970), 61;

44 Özler, "Tevhid", 19.

${ }^{45}$ Bk. Yûsuf 12/39-40; en-Nahl 16/75-76.

${ }^{46}$ Bk. Furkân 25/43; el-Câsiye 45/23.

${ }^{47}$ Bk. İsmail Raci Faruki, Tevhid, trc. Dilaver Yardım-Latif Boyacı, (İstanbul: İnsan Yayınları, 1995), 11; William Chittick, Varolmanın Boyutları, trc. Turan Koç, (İstanbul: İnsan Yayınları, 1995), 24; Temel Yeşilyurt, "Tevhidi Zedeleyen Söylemler", Hz. Peygamber, Tevhid ve Vahdet, (Ankara: DİB Yayınları, 2016), 133-136.

48 "Eğer yerde ve gökte Allah’tan başka ilahlar olsaydı, ikisi de bozulurdu” (el-Enbiyâ 21/22). Krş. elMü'minûn 23/91; el-İsrâ 17/42. 
kurallarıyla tek bir kudretin iradesine bağlama başarısını gösterir. Düzen ve kusursuz işleyiş üzerinde tefekkür, evrendeki ilişkiler ağının bir parçası olan kişiye bunları sürdürme ve onlara katkıda bulunma şeklinde özetleyeceğimiz sorumluluklarını hatırlatır. Bu sorumluluk, düzenin bozulmadan (ifsâd) devam ettirilmesi (1slah) ve bütün bir varlığın maslahatına uygun bir şekilde geliştirilmesidir (imar). Oldukça sınırlı sıfatlara sahip insanın bunu tek başına gerçekleştirmesi mümkün olamayacağından, hemcinsleriyle ve çevresini kuşatan diğer varlık formlarıyla işbirliği/dayanışma içinde olması gerekecektir. Bu bilinç, bir yandan toplumsal birlik, düzen, ahenk, tutarlılık ve dayanışmayı gerçekleştirmeye yönelik bir çaba içinde olan mü'min kişiliğin oluşmasına katk1 sunacak, diğer yandan da şirk ve ilkesizliğin doğuracağı toplumsal parçalanma, çelişki, aykırılık ve şaşkınlığı engelleyecektir. ${ }^{50}$

Kendisini kuşatan içsel ve dişsal bütün bir evrenle ilişki içinde olan ve bu ilişkiler bütününün bir parçası olan insan, bütün bir insanlık, hatta varlık âleminin, üzerine düşeni (ödev ahlâkı) yapmasını beklediği aktif bir üyesi olarak görülmelidir. Zira, onun ruh ve beden sağlığının muhafazası ya da bozulması sadece kendisini değil çevresini az ya da çok etkileyecek sonuçlar doğuracaktır. Bunun bir gereği olarak kişi, "bireysel hürriyetler" kavramına sığınarak kendi beden ve ruh dünyasına zarar verecek herhangi bir girişimde bulunamayacak, yeteneklerini yanlış yerlerde kullanma ya da körelterek pasifize etme yetkisine de sahip olamayacaktır. Tevhid inancı böylece insana kendisini kuşatan bütünü dikkate alan bir ilişki ahlâkı sunmakta ve ondan bunlara uymasını beklemektedir.

Tevhid, hayatı Allah'ın bütün varlıklara ortak lütfu olarak görmeyi, çokluğu ancak birlik ilkesi 1şığında algılamayı ve böylece çatışma alanlarını ortadan kaldırmayı hedefleyen bir zihin yaratmayı hedefler. Kâinatın tüm farklılık ve çeşitliliğine rağmen mükemmel bir uyum içinde bir ve bütün olarak nasıl var edildiğine ve işleyişine dikkatleri çekerek, en az birlik kadar çokluk ve farklılık kavramlarının önemine vurguda bulunur. Zihnini ve düşünme biçimini mutlak kudret sahibi olan, yaratmasında ve yarattıklarının hayatlarını devam ettirmelerinde onlara Rahman ve Rahim isimleriyle eşlik eden Tek bir varlık fikri etrafında ören mü'min, bunun arkasından böyle bir inanmanın gerektirdiği davranış tarzlarını da geliştirecektir. Bu anlamda o, salt bir dinî doktrin olmanın ötesine geçerek bir barış ve ünsiyet ilkesi halini alacak, kardeşlik kavramı sadece insanlığı değil bütün bir evreni de gerektiğinde içine alacak kadar genişleyecektir. Buna göre hangi varlık formuna, cinse, hangi 1rka, hangi millet ve kültüre, mensup olursa olsun bütün mevcudat Allah'ın yaratığıdır. ${ }^{51}$ Böylece, "yaratılanı Yaratan'dan dolayı sevme", şefkat ve merhamet gösterme duyguları gelişecek, hayvanından bitkisine, taşına toprağına kadar çevresine karşı daha duyarlı kişiliklerin çoğalmasına katkı sunacaktır.

\subsection{Meleklere İman ve Sorumlu Özgür Kişilik}

\footnotetext{
49 Bk. Mâtürîdî, Kitâbü't-Tevhî̀, nşr. BekirTopaloğlu-Muhammed Aruçi, (Ankara: Türkiye Diyanet Vakfı Yayınları 2003), 37-40; Ebu'l-Hasan el-Eş arî, Kitâbü'l-Luma 'fi'r-red 'alâ ehli'z-zeyg ve'l-bida', nşr. Abdulazîz İzzu'd-din es-Sirvânî, 1. Bask1 (Beyrut: Daru'l-Lübnan, 1987), 84; Ebu'l-Velîd Muhammed b. Ahmed b. Muhammed İbn Rüşd, el-Keşf (Felsefetü İbn Rüşd içinde), nşr. Mustafa Abdülcevâd İmrânî, (Kahire: y.y., 1388/1968), 70-77.

50 Bk. Celal Türer, "Tevhid ve 'Bir İnsanlık", Hz. Peygamber, Tevhid ve Vahdet, (Ankara: DİB Yayınları, 2016), 97

${ }^{51}$ Ali A. Aydın, "Peygamberimiz, İman Esasları ve Tevhid Akidesi”, 62-63; Şaban Ali Düzgün, "Allah'a İman”, İslâm İnanç Esasları, ed. Ş. Ali Düzgün, (Ankara: Grafiker Yayınları, 2013), 99, 102-103; Mehmet Görmez, "İnsanlığı Yaşatmak İçin Gelin Birlik Olalım”, Hz. Peygamber, Tevhid ve Vahdet, (Ankara: Di̇B Yayınları, 2016), 10.
} 
Kur'ân, Cebrâil, Mikâil, ${ }^{52}$ meleku'l-mevt (Azrâil), İsrâfil gibi dört melekten bahsettiği gibi, mukarrebîn, hameletü'l- 'arş, kirâmen kâtibin, mü'minleri koruyan hafaza, onları takip eden muakıbât, ${ }^{53}$ cennette mü'minleri selamlayacak olan cennet bekçileri (rıdvân), cehennemlikleri korkutup tahkir eden hazîn, mâlik ve zebânî adlı meleklerden de bahsetmektedir.54 Onlar, insanın her an yanı başında, onun her yaptığına şahit olan,55 Allah'ın her daim hazır ve nazır askerleri56 ve kullarıdırlar.57

Meleklerin Âdem'e secde ettirilmesi,58 ister hakiki ister mecazi59 anlamda alınsın, özgürlügünü sorumluluk alanlarıyla başarılı bir şekilde dengede tutabilen insanın "yeryüzünün halifesi" olmakla taçlandırılarak meleklerin bile secde edebileceği bir konuma yükselebileceğinin temsilidir. Bu düşünce ışığında kişi, kendisini bir iç kontrol ve eleştiriye tabi tutmak ve yeteneklerini geliştirmek için özel bir çaba harcamak suretiyle yaşamını şekillendirmesi gerektiğinin farkına varır. İnsandan beklenen üzerine aldığı görevi (emanet-hilafet) en iyi bir şekilde yapmak ve hayra yönelmektir. Bu bilince sahip bir kişilik ancak ifsadı engelleyip dünyayı imar etme yönünde bir atılımda bulunabilir.

Şuurlu varlıklar olan meleklerin görevlerini hem iyi yapması hem de iyilik için çaba sarf etmesi, iradelerini iyi yönde kullanmalar $1^{60}$ bu konuda insanların önünde bir örneklik alanı, yakalanmayı bekleyen birer hedef olarak durmaktadır. Allah'a karşı tam bir itaat içinde olmaları, sürekli insanların hayrına ve iyiliğine olan şeyleri dilemeleri ve onlara da bu şekilde davranmalarını ilham etmeleri, ${ }^{61}$ gıyaplarında Allah'tan bağışlanmalarını ve hayra kavuşmalarını istemeleri, inanan şahsiyet için birer örneklik teşkil etmektedir. Samimi mü'min kişilik, meleklere öykünerek, hem kendisi hem de kendini kuşatan evren için kötülüklerin asgarî düzeye indirgenip hayır ve güzelliklerin artması için uğraşmalı (emr-i bi'l-ma'rûf nehy-i ani'l-münker), takatini aşan durumlarda Allah'a sığınarak O'ndan yardım dilemelidir. Öte yandan, nasıl ki melekler, tabiattaki her bir unsurda içkin olan potansiyel/kuvve halindeki nitelikleri aktifleştirip kozmosa katk1 sunuyorsa, insanın da kendindeki yetileri/melekeleri aktifleştirip meleklerin tesis ettiği dengeyi muhafaza etmesi, yeryüzü işleyişine katkı sunması gerekir. Meleklerden alınan bu örneklikle insandan istenen iradesini ortadan kaldırması değil, hayra yönlendirmesi, iyiliklerini meleke haline getirerek, şeytanî karakter(liler)den uzaklaşıp melekleşme

\footnotetext{
52 el-Bakara 2/97-98.

${ }^{53}$ er-Ra'd 13/10-11.

${ }^{54}$ Bk. Ebu'l-Yusr Muhammed b. Hüseyin Pezdevî, Ehl-i Sünnet Akâidi, trc. Şerafeddin Gölcük, (İstanbul: Kayıhan Yayınları, 1980), 287-292.

55 en-Nisâ 4/166.

${ }^{56}$ Bk. Âl-i İmrân 3/124-125; el-Enfâl 8/9; et-Tevbe 9/26; el-Fetih 48/4, 7.

${ }^{57}$ Bk. en-Nisâ 4/172.

${ }^{58}$ Bk. el-Bakara, 2/30-34; el-A'râf, 7/11-12; el-Hicr, 15/28-33; İsrâ, 17/61; Kehf 18/50; Tâhâ 20/116; Sâd 38/71-76.

59 Meleklerin secdesini sembolik olarak görenlerden Ebu'l-Alâ el-Mevdûdî (ö. 1979), bu secdeyi, Allah'ın izin verdiği işlerde meleklerin insanlara yardım etmeleri ve gerekli müdahalelerde bulunmaları şeklinde yorumlarken, (Bk. Mevdûdî, Tefhîmu'l-Kur'ân, trc. Komisyon, (İstanbul: İnsan Yayınları, 1991), 1: 64.) Süleyman Ateş, “Âdem'e secde eden melekler, irade yeteneğini, akıl gücünü kazanan insana boyun eğen tabiat kuvvetleridir. İnsan akıl gücünü kazanınca tabiat kuvvetlerini emri altına almış, onlardan yararlanmasını, onların korkunç etkilerini önlemesini bilmiştir” diyerek anlamlandırır. (Bk. Süleyman Ateş, "Kur'ân-1 Kerîm'e Göre Evrim Teorisi” 20/1 (Ankara: AÜIIFD, 1972): 144. Benzeri ifadeler için bk. a.mlf, Kur'an Ansiklopedisi, (İstanbul: Kuba Yayınları, 1997), 1: 170.)

${ }^{60}$ Meleklerde şuur ve iradenin olduğuna dair bir araştırma için bk. Emrullah Fatiş, "Meleklerde Şuur ve İrade Problemi”, Kelâm Araştırmalart Dergisi 13/2, (2015): 785-806.

${ }^{61}$ Bk. Fussilet 41/30-32; eş-Şûrâ 42/5.
} 
yönünde adım atması, ilerlemesidir. Özgür iradesiyle karar vererek bunu gerçekleştirmesi, eylemlerine ve dolayısıyla kendisine değer yükleyen, onu meleklerin önüne geçiren esas nedendir.

Meleklere iman düsturu, iyiliğin gerçek bir güç, kötülükten elde edilen gücün ise arızi olduğuna, şeytanın insan üzerinde herhangi bir sultasının olmadığına ${ }^{62}$ inanmayı doğurur. Bu güç (iyilik-kötülük), ancak insan tarafından tercih edilmek suretiyle varlık bulan bir güçtür; meleği de şeytanı da davet eden (dâî) insanın bizzat kendisidir. Böylece gücü doğuranın; yani iyilik ve kötülüğün vücut bulmasında gerçek nedenin insanların özgür seçimi olduğunun bilincine varan kişi, yeryüzündeki kötülükleri kadere, göklere ya da şeytana havale etme hatasına düşmeyecek, sorumluluğu üzerine alma başarısını gösterebilecektir. Sorumluluğu üstlenmek ise, problemlerin çözümü için atılan ilk ve en önemli adımdır. Önünde şeytan ve meleklerin sunduğu seçeneklerle dolu rûhî bir hayatın olduğunu, meleklerin telkin ve teşviklerine göre hareket edip mevcut yeteneklerini bu yönde yükseltmesi gerektiğini kabul eden kişi hem kendisiyle hem de çevresiyle barışık bir hayat sürdürmeyi başarabilecektir.

Meleklere inanan kişi Allah tarafindan gönderilmiş yüce ve gizli güçlerin gözetimi altında olduğunu, Kirâmen Kâtibîn olarak bilinen meleklerin kendisinin bütün söz ve davranışlarını olduğu gibi kaydettiklerini bilir $^{63}$ ve bu bilinçle iyi şeyler yapmaya yönelir. Meleklerin görünmeyip gayp âleminde olması insanın, kendisiyle baş başa kaldığı anlarda bile hal ve hareketlerine çeki düzen vermesini, ma'rufâ yönelmesini sağlar, güçlü bir otokontrol sisteminin oluşmasına katkı sunar. Kur'ân'ın açık bildirimlerinden hareketle o, dar ve sıkıntılı anlarda meleklerin mü'minlerin yardımına yetişeceğine ${ }^{64}$ inandığından hiçbir zaman ümidini yitirmez; hayatın zorlukları karşısında azmini ve dayanma gücünü diri tutar. Zira meleklerin her zaman iyilerin yanında ve onların destekçisi, lanetleriyle de kötülerin amansız düşmanı olduğunu ${ }^{65}$ bilir. Böylece sorumluluklarını yerine getirmede daha istekli ve gayretli olur.

Gözetleme esnasında meleklerin doğrudan müdahalelerinin olmaması, insanların özgürce ve samimi bir şekilde karar almalarını sağlar. Bu, hür iradeyle verilecek kararlara saygının bir nişanesidir. Nitekim iyiliğe yönelik daveti kabul edip etmeme de özgür bir iradenin kararı olacaktır. Bundan dolayıdır ki müdahalenin olmadığı bir kayıt ya da kontrol, hürriyetleri engellemek bir yana onları koruma altına alan garantör hükmündedir. Yapılanların kayıt altında olduğunu bilmek, bir yandan başkalarının haklarına riayet etmeye ve özgürlük alanlarına saldırmamaya yönelik hassas bir bilincin oluşmasına önemli katkılar sunarken bir yandan da kendi hak ve özgürlüklerimizi koruma altına alır.

Meleklere imanın insanda sorumluluk bilinci oluşturması onun ihtiyar sahibi özgür bir varlık olmasıyla doğrudan ilgilidir. Cebr altında yapılan eylemler, yeteneklerinin körelmesine, eylemin bizzat kendisinden kaçışa ya da aksini yapmaya yönelik bir karakter oluşumuna yol açacaktır. Müdahalenin olmadığı özgür bir ortamda kişi kendi özgür seçiminin bir sonucu olarak yaptıklarını sahiplenecek, karşılaşacağı muhtemel sonuçlardan başkalarını sorumlu tutmaktan vazgeçecek, bununla kaybedeceği zamanı

\footnotetext{
${ }^{62}$ Bk. İbrahim 14/22; Hicr 15/42; en-Nahl 16/99-100; İsrâ 17/65; Sebe 34/20-21. Krş. en-Nisâ 4/76.

63 "Onun sağında ve solunda oturan iki elçi kaydetmektedir. (İnsan) hiçbir söz söylemez ki yanında (onu) gözetleyen, yaptıklarını zapt eden (bir melek) hazır bulunmasın.” (Kaf 50/17, 18). Ayrıca bk. el-İnfitâr 82/10-12; ez-Zuhruf 43/80; et-Târık 86/4; er-Ra'd 13/11.

64 Âl-i İmrân 3/123-125; el-Enfâl 8/12.

65 el-Bakara 2/161-162; Âl-i İmrân 3/86-87; eş-Şûrâ 42/5.
} 
hata, eksik ve kusurları telafi edip daha iyisini yapmada kullanarak yeniden kazanacaktır.

\subsection{Peygamberlere ve Kitaplara İman ve Sorumlu Özgür Kişilik}

İnsanlara doğru yolu göstermek amacıyla Allah tarafından seçilmiş insanların Allah'tan getirdiği bütün bilgilerin gerçek ve doğru olduğuna inanmak şeklinde tanımlanabilecek olan peygamberlere ve kitaplara iman, birbirini tamamlayan ve gerektiren iki önemli ilkedir. Kitaplara iman eden, hiçbir ayırım gözetmeden içindeki bilgilerin tamamına iman eder. Tersten bir okumayla peygamberlere iman etmeyen de Allah'a iman hariç, zincirleme olarak diğer esaslara da iman etmez ya da onlar hakkında derin bir kuşku içine düşer. O ya ateisttir ya da sadece Tanrı'ya inanan bir deist, panteist veya belirli açılardan panenteisttir. ${ }^{66}$

İnanç açısından insan fitratına en uygun olan tavır, yaratıcı bir gücü kabul edip ona bağlanmaktır. ${ }^{67}$ Ancak çoğu zaman insanda bu inanç çeşitli etkilere maruz kalarak hırpalanır, şirke bulanır ve insana verilen hürriyetin bir nişanesi olan tevhitten uzaklaşır. Peygamber gönderilmesindeki gayelerden biri de manipülasyona uğrayarak yanlış yönlere kayan Tevhid inancını yerleştirmek, yeniden diriltmektir. Bunun anlamı, müstağni olan Allah'1 yüceltmenin ötesinde, başka ellere teslim ederek kaybettiği hürriyetini ve dolayısıyla şerefini insana yeniden iade etmektir.

Peygamberler ve kutsal kitapları, aklın yanında insanların Allah ve evrenle iletişimini sağlam bir zemin üzerinden kuran ve muhafaza eden iki unsur olarak görmek gerekir. ${ }^{68}$ Bunların aradan çıkarılmasıyla, insanın gereksiz bağlardan kurtulup gerçek hürriyetini eline alacağı ve böylece Allah'la daha kuvvetli bir iletişime kavuşacağı fikri, yanlış öncüllere müracaatın doğurduğu yanlış bir sonuç olarak değerlendirilmelidir. İslam, insanı hürriyetinden eden ve Yaratıcısı'ndan uzaklaştıran her türlü aracıyı elbette ki şiddetle reddetmiş; Yaratan-yaratılan ayırımının bilincinde olarak, gerçek anlamda Allah'a yaklaştıracak her türlü vesileye ${ }^{69}$ (Peygamber, Kitap, melek, bütün bir kainat,

\footnotetext{
66 Vahyin ya da nübüvvetin imkânının sadece Tanrı'nın varlığıyla değil, nasıll(algıland)1ğıyla da alakalı olduğunun bu kavramlar üzerinden bir anlatımı için bk. Recep Kılıç, Modern Batı Düşüncesinde Vahiy, (İstanbul: Ötüken Yayınları, 2004), 158-159.

67 ...Fakat Allah, size imanı sevdirmiş ve onu gönüllerinize güzel göstermiş; inkârı, fâsıklığı ve isyanı da çirkin göstermiştir...” (el-Hucurât 49/7);“...İ̧ste Allah onların kalplerine imanı yazmış ve onları kendi katından bir ruh ile desteklemiştir...'(el- Mücâdele 58/22)

${ }^{68} \mathrm{Mu}$ 'tezile nübüvveti adalet kavramı üzerinden temellendirirken (Bk. Kādi Abdülcebbâr, el-Muhtașar fí uṣ̂uli'd-dîn, (Resâilu'l- 'adl ve't-tevhîd içinde), nşr. Muhammed Umâre, (Kahire: Dâru'l-Hilâl, 1971), 1: 236) İmam Mâtürîdî lütuf ve rahmet anlamındaki hikmet kavramına vurguda bulunur. Bk. Mâtürîdî, Te'vîlâtu'l-Kur'ân, 3: 183; 9: 417; 12: 76; Krş. Kitâbu't-Tevhîd, 192. Eş'arîler ise Allah'1n peygamber göndermesini bir lütuf olarak görmekte, göndermediğinde ise mâliku'l-mülk olan ve mülkünde dilediği şekilde tasarruf yetkisine sahip olan Allah için bunun (Mu'tezile'nin aksine) sefeh ya da zulüm olarak nitelenemeyeceğini belirtirler. Bk. Ebû Bekr Muhammed b. Tayyib b. Muhammed el-Basrî el-Bâkıllânî, el-İnṣ̂f fî mâ yecibu i 'tikāaduhu velâ yecûzu'l-cehlu bihi, nşr. İmâduddîn Ahmed Haydar, (Beyrut: 'Âlemu'l-Kutub, 1407/1986), 92-93; Ebû Hâmid el-Gazzâlî, el-ỉktișâd fi'l-i 'tiķâd, nşr. İ. Agâh ÇubukçuHüseyin Atay, (Ankara: y.y., 1962), 121. Krş. İmâmu'l-Haremeyn Ebü’l-Meâlî Rüknüddîn Abdülmelik b. Abdillâh b. Yûsuf el-Cüveynî, Kitâbu'l-irşâd ilâ kavâtı 'i'l-edille fì usûli'l-i 'tikād, nşr. Es'ad Temîm, (Beyrut: Dâru'l-Kutubi'l-İlmiyye, 1405/1985), 259-260. Benzeri görüş için ayrıca bk. Nesefî, Tebșıratü'ledille, 1: 448 ve Sâbûnî, el-Bidâye fì uṣ̂ûli'd-dîn, 45. Mu'tezile peygamberlerin gönderilmesinin Allah üzerine vacip olduğunu söylerken Ehl-i sünnet âlimleri bunu imkân dâhilinde görür.

${ }^{69}$ ez-Zümer 39/3 ayeti, Allah'ı bırakıp kendilerine bir takım dostlar edinenlerin, bu niyetlerinin aksine “Biz onlara sadece, bizi Allah’a daha çok yaklaştırsınlar diye ibadet ediyoruz” dediklerini aktarır.
} 
enfüs ve afaktaki bütün deliller) inanmayı ve müracaatı ise teşvik etmiş, ${ }^{70}$ gerçek hürriyetin adresine göndermede bulunmuştur. ${ }^{71}$ İkisi arasındaki esaslı fark, kişinin hem iç hem de dış dünyasında Allah'a yaklaşmasıyla (yalnız O'na kul olup, yalnız O'ndan istemekle özgürleşmesi) uzaklaşması (aracı unsurların kölesi olma) arasındaki gerilimde aranmalıdır. Tanrısal olanın ötelenerek yok mesabesine indirgenmesiyle, insanın kendisi ve çevresiyle olan ilişkilerinin keyfiyetini belirlemede öne çıkan kavram, Tanrısal olan değil; beşerî olan, mutlak bir gücün hakemliği değil; güçlü olanın beşerî zaafları olacaktır. İnsan onuruna yakışır özgürlük, Tanrısal olanı değil beşerî zaafları aradan çıkarmaktır. Bu, özgür kimliğini kazanabilmesi için inananın yerine getirmesi gereken önemli sorumluluklarındandır.

Ak1l, iyinin ve kötünün belirlenmesinde belli düzeyde bir hüküm vericidir ve peygamberlerin getirdiklerini kabulde ve kavramada birincil muhataptır. Ancak hiçbir akı1, aklın yanılmaz olduğunu söyleyemez. Dolayısıyla, içsel ve dışsal pek çok faktörün etkisinde kalan insan aklının her zaman için doğruyu bulmada isabet ettiğini söylemek yanlış olur. ${ }^{72}$ Aynı şey Kutsal kitapları okuyup oradan aklıyla belli çıkarımlarda bulunması gereken inanan için de geçerlidir. Mananın tam olarak kavranabilmesi için zaman zaman, iyi anlaşılamayan, müphem yönleri açıklamak ve insanları en iyi ve doğru olana yönlendirmek için gönderilmiş peygamberlerin açıklamalarına ve hakemliğine ihtiyaç duyulacaktır. Peygamber ve kitap göndermek; aklın da onaylamasıyla, insanlara yardım ve yol göstermek, hatırlatmak, onları uyarmak ve yanlışa dikkat çekmektir. ${ }^{73}$ Peygamberlerin bu davetine uymak ve gereğini yerine getirmek, hürriyete ket vurmak değil, aksine kişiyi beşerî zaaflarının handikaplarından kurtararak özgürleştirmektir. Zira ne peygamberler kendilerine uyulması konusunda insanları zorlamış, ne de kutsal metinlerde kendilerine bu yetki verilmiştir; dileyen iman eder, dileyen inkâr eder. ${ }^{74}$ Kur'ân inanıp inanmamayı, va'z ettiği kurallara uyulup uyulmamasını insanın özgür iradesine havale ederek inananından samimiyet istemekte, bunu bir yaşam tarzına dönüştürmesini de kendisinden beklemektedir. Dinde zorlamanın olamayacağını bildiren ayetler ${ }^{75}$ bunun en kuvvetli delilidir.

\footnotetext{
${ }^{70}$ Bk. “Ey iman edenler! Allah’tan korkun, O’na yaklaşmaya vesile arayın ve O'nun yolunda çaba harcayın ki kurtuluşa eresiniz" el-Mâide 5/35

${ }^{71}$ Kur'ân bunu "hablullah" kavramılla ifade etmiş, hablullah dışındaki herhangi bir şeye bağlanmayı/dost edinmeyi ayrılık ve aykırılığın gerekçesi olarak sunmuştur. Bk. el-Mâide 3/103.

72 İmam Mâtürîdî Peygamber gönderilmesinin gerekçeleri arasında şunları söyler: "Peygamber bütün akıllar (insanlar) arasında bir hakemdir. Peygamber akla yardımcı ve onun danışmanı olarak onun sorunlarını çözer ve ortadan kaldırır, yükünü hafifletir. Akıl da danışmaya, öğrenmeye meraklı olarak yaratılmış olduğundan Peygamber'in getirdiğini düşünmeye sonuç çıkarmaya kendini teşvik eder. Akla Peygamberden başka yardımcı olmaya daha layık kim olabilir? Akıl da peygamber de Allah'ın elçisidir." Bk. Kitâbü't-Tevhîd, (Beyrut: y.y., 1970), 182-186; Benzer düşünceler için bkz. Râgıb el-İsfahânî, Tafsîlü'n-neş'eteyn ve tahsîlü's-se âdeteyn, nşr. Abdülmecîd en-Neccâr, (Beyrut: Dârü'l-Garbi'l-İslâmî, 1408/1988), 141.

${ }^{73}$ Peygamber göndermenin sebepleri hakkında bk. Mâtürîdî, 275-276, 280, 284, 354; a.mlf, Te 'vîlâtu'lKur'ân, 2: 375, 4: 262, 7: 19; Bâkıllânî, Kitâbü Temhîdi'l-evâ'il ve't-telhîsüu'd-delâ'il, nşr. İmâdüddîn Ahmed Haydar, (Beyrut: Müessesetü'l-Kütübi’s-Sekâfiyye, 1414/1993), 145; Sâbûnî, el-Bidâye, 45; Teftâzânî, Şerhu 'l- 'Aķā 'id, (İstanbul: Bahar Matbaası, 1973), 164 vd.

${ }^{74}$ el-Kehf 18/29. Benzeri ayetler için bk. Âl-i İmrân 3/20; el-En'âm 6/107; Yûnus 10/ 99,108; ez-Zümer $39 / 41$.

75 el-Bakara 2/256. Ayrica bk. el-Ğâşiye 88/21-26; eş-Şûrâ 42/48; el-Mâide 5/92, 99; en-Nahl 16/35, 82; en-Nûr 24/54; Ankebût 29/18; Yasin 36/17; et-Teğâbun 64/12.
} 
Peygamber ve kitap göndermek suretiyle kullarına yardım, merhamet ve lütufta bulunan Yaratıc1 ${ }^{76}$ bu tavrıyla, kullarından da güçleri yettiğince yardımlaşmalarını, zayıf ve aciz olan diğer varlıkları koruyup gözetmelerini istemiş ve bunu da bir imtihan vesilesi kılmıştır. $\mathrm{Bu}$ şekildeki bir imtihan öğretisiyle $\mathrm{O}$ aslında, başkalarına yardımın, haddizatında ve esas olarak insanın kendine yardımı olduğunu göstermek istemiştir. İnsan dünyevî ve uhrevî sonuçlarına katlanmak suretiyle ${ }^{77}$ bunlara uyup uymamakta serbesttir. Hz. Peygamber bu konuda model şahsiyet olduğu gibi ümmetinden de aynı tavrı sergilemelerini istemiştir. Bu özgürlüğün (dünyevî veya uhrevî) bir hesabının olması, insanın kararlarından ve kararlarının sonuçlarından sorumlu olduğunun göstergesidir. Sorumluluğu uygulanabilir kılan ise Allah'ın, insanları güçlerinin üstünde herhangi bir şeyle mükellef tutmayacağına ${ }^{78}$ dair va'didir.

Peygamberlere iman, peygamberlerin de Allah'ın kulu ve elçisi olduğunu bilme şuuruyla Allah'tan başka ilah/rab edinmemeyi ilzam eder. İslam inancı, peygamberlerini ve din adamlarını rabler edinen Hıristiyan anlayışa karşı çıkarak Allah ile kulları arasında ilahlık ve rablik anlamında her türlü aracıyı ortadan kaldırmış, imtihan öğretisinin bir gereği olarak insanı özgürlüğüyle baş başa bırakmıştır. İslam inanç sitemi, tahrif olmuş ya da uydurulmuş bu tür inanç sistemlerinin aksine Tevhid inancının yerleşmesi için peygamberleri birer aracı, elçi kılmıştır. ${ }^{79}$ Kur'ân, Hz. Peygamber'in, bir beşer olarak, yaptığı bazı hatalarından ve Allah'ın da bunlardan dolayı kendisini uyararak öğüt verdiğinden bahsetmektedir. ${ }^{80}$ Peygamberlerin bile hata (zelle) edebileceklerinin bildirilmesi, hiçbir insanın hatasızlığa ve kutsallığa ulaşamayacağını anlatma gayesini gütmekte, ${ }^{81}$ Allah dışında ilahlar; peygamberler ve melekler dışında "masumlar/kutsallar sınıfı" edinmenin ve iradesini bunlara teslim etmenin tehlikelerine işaret etmektedir.

Peygamberlerin beşer olmasındaki en büyük gaye, getirdikleri vahyin anlaşılmasını ve yaşama aksettirilmesini kolaylaştırmaktır. Hıristiyanlar peygamberleri beşerî özelliklerden sıyırarak onlara ulûhiyet atfederken, müşrikler "melek olmalı değil miydi?"82 diyerek melek misal bir varlığı peygamber olarak tahayyül etmişlerdir. Bu istekleriyle onlar, eski alışkanlık ve nüfuzlarının devamı adına herhangi bir sorumluluk üstlenmeden, hayatın içinde ve hayata müdahil olmayan bir varlığ görmek istiyorlardı. Öte yandan, eğer melek inecek olsaydı, insanın inanıp inanmama serbestliği ortadan kalkacak, inanmadığı takdirde de helak olacaktı. Şayet melekten

\footnotetext{
76 Bk. “...Allah'a karşı kullanacakları bir delilleri olmasın diye Allah, peş peşe peygamberler göndermiştir..." (Nisâ 4/164-165). Vahiy ve Peygamber göndermenin gaye ve gerekçeleri hakkında geniş bilgi için bkz. Hülya Alper, "Kelâm İlminde Aklın ve Vahyin Yeri”, Akâid ve Kelâm İlminde Aklın ve Vahyin Yeri- Tartışmalı İlmî İhtisas Toplantısı, (İstanbul: 20-21 Ekim 2012): 115-154; a.mlf. "İmam Mâtürîdî’de Akıl-Vahiy İlişkisi: Aklın Önceliği ve Vahyin Gerekliliği”, Milel ve Nihal 7/2, (MayısAğustos 2010: 6-29; Cemalettin Erdemci, "Kelâm İlminde Akıl ve Naklin Etkinliği Problemi”, Kelâm İlmi’nin Yeniden İnşasında Geleneğin Yeri Koordinasyon Toplantısı ve Sempozyum Bildirileri, (Elazı̆̆. Fırat Üniversitesi İlahiyat Fakültesi, 2004), 329-344.

77 "Yoksa insan başıboş bırakılacağını mı zanneder" (el-Kıyâme 75/36)

${ }^{78}$ Bk. el-Bakara 2/185, 286; et-Tegābün 64/16.

79 "Senden evvel gönderdiğimiz hiçbir peygamber yoktur ki kavimlerine benden başka ilah yoktur ve yalnız bana ibadet edin demiş olmayalım" (el-Enbiyâ 21/25); "De ki: "Ey kitap ehli! Bizimle sizin aranızda ortak olan bir söze gelin: Yalnız Allah'a ibadet edelim. O’na hiçbir şeyi ortak koşmayalım. Allah'ı bırakıp da kimimiz kimimizi rab edinmesin.' Eğer onlar yine de yüz çevirirlerse, deyin ki: 'Şahit olun, biz Müslümanlarız." (Âl-i İmrân 3/64)

${ }^{80}$ et-Tevbe 9/32,84; el-Enfâl 8/67-68; el-Ahzâb 33/37; Abese 80/1-10.

${ }^{81} \mathrm{Bk}$. Atay, İslâm'ın İnanç Esasları, (Ankara: AÜ̇iF Yayınları, 1992), 176.

${ }^{82}$ Bk. el-En'âm 6/8 el-Furkân 25/7-8; el-İsrâ 17/94-95. "Ya da yanında melek olmalıydı.” Bk. Hûd 11/12.
} 
peygamber gönderilecek olsaydı, Allah insanın inanma hürriyetini muhafaza için yine beşer suretinde bir melek gönderirdi. $O$ zaman da melek olduğunu anlamayacak ve inanmamaya devam edeceklerdi. ${ }^{83}$

"Muhammed Allah'ın elçisi ve peygamberlerin sonuncusudur. Hiç birinizin babası da değildir" (el-Ahzâb 33/40) ayeti, Peygamber soyundan gelmenin, özgürlüğe vurulan darbelerden biri olan ve sorumluluk ahlâkını zedeleyen (dünyevî veya uhrevî) sınıfsal bir ayrışmaya ya da bir takım kişisel menfaatlerin kazanımına götürecek bir ayrıcalık olarak görülmemesi gerektiğini ifade etmektedir. ${ }^{84}$ Nitekim Hz. Peygamber kızına hitaben şunları söylemiştir: "Ey kızım Fâtıma! Babam peygamber diye güvenme. Rabbine karşı kulluk vazifeni yap. Eğer Allah'tan nefsini satın alamazsan vallahi ben bile senin namına hiçbir şey yapamam..."85 $\mathrm{O}$, bu sözleriyle, insanın dünyada hem kendisine hem de çevresine (Allah-evren) karşı olan çift yönlü sorumluluğunun karşılığını/hesabını, ahirette herhangi bir ayrıcalığa uğramadan, bireysel olarak vereceğini ${ }^{86}$ göstermek istemiştir. Aynı hassasiyetin dünyevî cezalar için de gösterilmesi gerektiğini yine kızı Fâtıma üzerinden şu şekilde dillendirir: “...Sizden öncekileri helak eden; ancak onların içlerinden şerefli ve soylu birisi hırsızlık ettiği zaman onu cezasız bırakmaları, içlerinden fakir ve zayıf biri hırsızlık edince de onun hakkında ceza uygulamaları idi. Vallahi hırsızlığı sabit olan Mahzumoğulları'ndan Fâtıma değil, kızım Fâtıma bile olsa, ayırım yapmaz, cezasını verirdim." da dahil olmak üzere toplumun rağbet gösterdiği her türlü imkânı istismar ederek kullanma eğiliminde olan fırsatçıların önünü daha baştan kesmek istemiştir.

Peygamber aklı, vahyi en iyi anlayan ve tatbik eden akıldır. Bu aklın örnek alınması (sorumluluk üstlenme) gerektiğini Kur'ân bildirir. İnsanüstü bir varlığın örnek alınması imkânsızlaşacağından ${ }^{88}$ Kur'ân buna imkan vermeyerek peygamberlerin dilinden "kendilerine vahiy inen beşer (sorumluluk üstlenen varlık)" yönlerini ön plana çıkarmıştır. Peygamberin, melekten olmuyorsa da en azından içinden çıktıkları kavmin ileri gelenlerinden, nüfuzlu kişilerden olması gerektiğine dair iddia ${ }^{90}$ da tam bir hürriyet ve örneklik için sakıncalı ve eksik görüldüğünden reddedilmiştir. Nitekim Kur'ân, genel bir kanaat olarak, şehrin ileri gelenlerinin (mele'), şımarıklık ve taşkınlıklarından dolayı, kötü birer örneklik teşkil ederek, halkı da kendileriyle beraber helake sürüklediklerinden bahseder. Onun önerdiği ölçüler farklıdır ve bu ölçüler Akâid kitaplarında doğruluk, emanet, ismet, fetânet ve tebliğ şeklinde sıralanmıştır. İlk dört özellik, esas olarak tebliğ vazifesini tam olarak yerine getirmenin zorunlu şartları olarak da görülebilir. Bu görev yerine getirilirken özgür iradeye saygı duyulması gerektiği, başta Allah'ın böyle bir zorlamada bulunmadığından hareketle vurgulu bir şekilde ifade

\footnotetext{
${ }^{83}$ Atay, Kur'an'da Iman Esaslart ve Kader Sorunu, 119.

84 Özellikle Doğu ve Güneydoğu Bölgelerinde, kan davaları da dahil olmak üzere, aralarında husumet bulunan toplumsal kesimlerin, Hz. Peygamber ve ailesine duyulan sevgi, sayg1 ve hürmetin bir göstergesi olarak, o soydan geldiklerine inandıkları ailelerin aracılığıyla barışma yolunu tercih ettiklerini ve bu anlamda toplumsal barış ve huzura katkı sunulduğunu da ayrıca belirtmek gerekir.

85 Buhârî, "Vesâyâ", 11, "Tefsir", 2; Müslim, "İman”, 89, Hadis no:351.

${ }^{86}$ Hiç kimsenin bir başkasının günah yükünü yüklenmeyeceğine dair ayetler için bk. Fâtır 35/18; enNecm 53/38; el-İsrâ 17/14-15; ez-Zümer 39/7. Krş. en- Nûr, 24/54; Lokmân 31/33.

${ }^{87}$ Buhârî, "Enbiyâ", 34, "Meğâzî, 53; "Hudûd, 11,12; Müslim, "Hudûd", 8-9; Ebû Dâvûd, "Hudûd", 4; Tirmîzî, "Hudûd”,6; Nesâî, "Sârik", 6; İbn Mâce, "Hudûd”, 6.

${ }^{88}$ Kur'ân bunu şu şekilde dile getirir: "De ki: 'Eğer Yeryüzünde (insanlar yerine) yerleşip dolaşan melekler olsaydı, elbette onlara gökten bir melek peygamber indirirdik', “el- İsrâ 17/95.

89 el-Kehf 18/110; Fussilet 41/6.

90 Sâd 38/8; ez-Zuhruf 43/31.
} 
edilmiştir. ${ }^{91}$ Bir peygamberde bulunması gereken bu ortak özellikleri, aynı zamanda inananların da güçleri oranında (istitaat) gerçekleştirmeleri beklenen birer hedef olarak görmek yanlış olmaz.

Peygamberlere iman eden kişi için onların getirdiklerine iman kadar örnek yaşantılarına ittiba da önem arz edecektir. Bunun içindir ki Peygamber kıssalarından bahseden Kur'ân, inananın dikkatini, onların mu'cizevî yönlerinden ziyade örnek kişiliklerine, hürriyetlerini kullanma biçimlerine ve başkalarının hürriyetine duydukları saygıya çekmek istemiştir. İslam'ın önerdiği örnek kişiliğin oluşmasında, iman edilen peygamberleri taklitten ziyade örnek alıp onların öğretilerini hayata aksettirmek önemli bir ilkedir. Kur’ân Hz. Peygamber'e hitaben: “(Ey Resulüm!) Muhakkak ki sen, en yüce bir ahlâk üzeresin" (el-Kalem 68/4) şeklinde buyurmuş, Hz. Aişe de onun ahlâkının Kur'ân ahlâkı olduğunu bildirmiştir. Bu demektir ki peygamber ahlâkıyla ahlaklanmak, haddizatında Kur'ân ahlâkıyla ahlaklanmak, Kur'ânî ilkeleri bizzat yaşama dahil ederek ete kemiğe büründürmek, idealizm belirsizliğine düşmekten kurtarmaktır. Burada inanandan istenen, körü körüne bir itaat değil, bilinçli ve kendinden emin bir iştiraktir. $\mathrm{O}$, bunu ne derece gerçekleştirebildiği noktasında ise sınanacaktır. Nitekim söz konusu ayetin devamında Allah, aynı şeyi "yüce ahlâk" sahibi olmanın bir gereği olarak bizzat Peygamberden istemiş, kendi hak yolundan sapıp yalanlayanlara, “...yemin edip duran, aşağılık, daima kusur arayıp kınayan, durmadan söz taşıyan, iyiliği hep engelleyen, saldırgan, günaha dadanmış, kaba saba, bütün bunların ötesinde bir de soysuz olan kimseye mal ve oğulları vardır diye" (el-Kalem 68/7-14) boyun eğmemesini, onlara karşı tavizkâr bir tutum sergilememesini salık vermiş, gerçek özgürlügün adresine göndermede bulunmuştur.

Kur'ân, sergilediği yöntemi inananlarından da beklemektedir. Fikirlerini savunurlarken hüccet, bürhan, delil getirmelerini, muhataba göre hareket edilmesi gerektiğini ve tedricî yöntemin hayata geçirilmesini salık verir. Öfkeyi yutma, yumuşak söz söyleme, kendisi ve sevdikleri aleyhine de olsa doğruluktan sapmama, adalet ve ihsanı her şeye rağmen ayakta tutma, merhametli olma, yardımlaşma/dayanışma vs. Kur'ân'ın önemle üzerinde durduğu ahlâkî ilkelerden bazısıdır. O ayrıca insanı kuşatan evrenin pasif bir varlık kategorisi olarak algılanmayıp ona, mârifetullaha yönlendiren birer münadi nazarıyla bakılmasını ister; fakat kişiyi buna zorlamaz. Kur'ân bu çabayı da istidlal ve nazar yöntemiyle insandan beklemekte, aynı tavrın Peygamber kıssaları için de gösterilmesini istemektedir. Peygamberlerin karşılaştıkları sıkıntılardan mu'cizelerle değil, tevbe de dahil olmak üzere kendi irade ve gayretleriyle kurtulduklarını, sonradan gelenlerin de bunu modelleyerek yaşamlarına aksettirmeleri gerektiğini "İnsan için ancak çalıştığ vardır" (en-Necm 53/39) ayetiyle ${ }^{92}$ irdelemektedir.

\subsection{Ahiret Gününe İman ve Sorumlu Özgür Kişilik}

Ahirete iman, kararlarında özgür ve sorumlu kılınan insanın, bu özgürlüğünü ve sorumluluğunu ne derece yerinde kullandığının teste tabi tutularak karşılığının verileceği bir zeminin ve zamanın varlığına duyulan imandır. Yaratılıştaki gaye ve hikmete göre davranmayı öğreten ve hayata yön veren bu ilkeyle kişi, yaptıklarının mutlaka hesabını vereceğini bilerek hal ve hareketlerine çeki düzen verecek, kötülüklerden uzaklaşıp Allah'ın rızasını kazanacak fiillere yönelecektir. Dolayısıyla,

\footnotetext{
${ }^{91}$ Bk. el-Bakara 2/256; el-Mâide 5/99; Yunus 10/99; Kehf 18/29; eş-Şûrâ 42/48; Kâf 50/45; Abese 80/1112; el-Gâş̧iye 88/21-22.

${ }^{92}$ Krş. el-İsrâ $17 / 13$.
} 
insanın yapıp etmelerinin karşılık bulacağı kalıcı bir var oluş alanı ile ahlâk temelli bir bilinç düzeyi yaratma arasındaki bu sıkı ilişki, insanda kuvvetli bir sorumluluk bilincinin gelişmesine katkı sunacaktır.

İslam teolojisinde ahirete iman, sadece bir umut ya da beklenti teolojisi değil, en az onun kadar bu dünyaya ilişkin ahlakî görev ve sorumluluk süreçlerini de kapsayan bir ilkedir. Nitekim Kur'ân'ın ahiret tasavvuruna bakıldığında onun, ahireti dünyadan bağımsız bir şekilde ele almak yerine dünyayla ilişkili; dünya hayatını daha iyi ve yaşanılabilir hale getirme bağlamında ele aldığı, bu dünyadaki yaşamı ahlâkî temeller üzerinde inşa etmenin temel ilkelerini kodladığı görülmektedir. Kur'ân, dünyadaki nasibin unutulmadan ahiret hayatının hedeflenmesini öğ̈̈tler. ${ }^{93}$ İnsanın boş yere yaratılmadığını, başıboş bırakılmayacağını, öldükten sonra diriltilip Allah'ın huzuruna çıkarılacağını bildirir. ${ }^{94}$ Bundan dolayıdır ki ahiret, sadece son, tükeniş gibi sınırlı bir anlam içermez, bunların yanında var olmaya devam etme, dünyaya değer merkezli bağlanma, her hal ve şartta ümit taşıma anlamlarını da içerir. O, ahiret hayatı cihetiyle, en iyinin gerçekleşme imkânını gösteren umut, dünya hayatına bakan yönüyle de bir yaşam ilkesidir ${ }^{95}$ denebilir. Bu ilkenin insan bilincine yüklediği esas anlam, insana önce dünyasını, sonra da dünya hayatı üzerinden ahiretini belirleme hürriyetinin verilmiş olmasidir.

Gerçek adaletin gerçekleşeceği ahiret hayatı, bu dünyadaki sorumluluk bilinci ile öteki dünyadaki mutluluk arasında kesin ve vazgeçilmez bir bağlantı kurmaktadır. Bu iki var oluş süreci insanda, adalet ve ahlâk hissinin sürekli aktif ve canlı kalmasını sağlayarak, onu motive eder. Bir öte âlem düşüncesi ve bu âlemin şeklinin ve renginin yegâne belirleyicisinin insanın bu dünyadaki amelleri olduğu fikri, dünyayı imar ve inşada, ona katkı sunmada kişiyi harekete geçirir. Ahlâkı üstün bir değer olarak belirleyen ve bütün yaşamın bu ve benzeri değerler üzerine inşa edilmesini salık veren Kur'ân bunu, ahirete imanın gerekçesi ve temel dayanağı kılmıştır. Buradan hareketle, ahiret hayatının dünya hayatını anlamlı kılan en önemli motivasyon kaynaklarından biri olduğu rahatlıkla söylenebilir.

Ahirete iman, sorumluluklarını idrak etmeyenlerin, dünyada bazı sorumluluklardan sıyrılsalar bile İlâhî sorumluluktan ve Allah'ın huzurunda hesap vermekten kaçamayacaklarını, dünyevî yaptırımlardan kurtulsalar bile, uhrevî azaptan kurtulamayacaklarını haber verir ve onlar üzerinde yaptırım gücü oluşturur. Peygamberler müjdeleyici ve uyarıcı olma görevlerini, Kur'ân da "Eğer Allah'a ve ahiret gününe inanıyorsanız..." şeklindeki gereklilik bildiren hitabıyla, bazen güzel bir davranışın yerleşmesine ${ }^{96}$ bazen kötü bir fiilden kaçınılmasına ${ }^{97}$ yönelik emrini, Allah'a imanla birlikte zikrettiği bu esas üzerinden iletmiştir. Keza "dönüşün ancak Allah'a olacağını" bildiren ayetler de ${ }^{98}$ dünyayı ma'mur etmesi beklenen ve bunun için halife kılınan insanın sorumluluklarını, ahirete iman ilkesi üzerinden anlatmanın vurgulu bir şeklidir.

\footnotetext{
93 Bk. el-Kasas 28/77.

${ }^{94}$ Bk. el-Mü'minûn 23/115; el-Ḳıyâme 75/36-40.

95 Bk. Mahmut Ay, “Ahirete İman”, İslâm İnanç Esasları El Kitabl, edt. Ş. Ali Düzgün, (Ankara: Grafiker Yay., 2013), 239-243; Ömer Aydın, İslam İnanç Esasları,( İstanbul: İşaret Yayınları, 2012), 167-168.

${ }^{96}$ Boşanan kadınlara adaletle davranılması gerektiğini bildirmek üzere bk. et-Talak 65/2.

97 Yeryüzünde bozgunculuk/fesat çıkarılmaması gerektiğini bildirmek üzere bk. Ankebut 29/36.

98 “Dönüş banadır” (el-Hac 22/48; Lokman 31/14) “Dönüşünüz banadır” (Lokman 31/15), "Dönüş O’nadır”( el-Mü'min 40/3), “Dönüşünüz O’nadır’( el-Bakara 2/156), “Dönüşünüz hep O'nadır”( Yunus 10/4), “O’na döndürüleceksiniz” (Yasin 36/83), “Hakk'ın huzuruna götürüleceksiniz”(et-Tevbe 9/105)
} 
Ahirete iman, dünya hayatının hakkaniyet ve insaf ölçüleri içinde sürdürülmesini, ahirete yönelik bazı kavramlar üzerinden de inşa eder. Kur'ân'ın ahiretteki yargılama esnasında söz konusu ettiği kabir ve berzah hayatı, klyamet alametleri, Haşr-mahşer, defterlerin dağıtılmasl, hesap, mîzan, sırât, A'râf, cennet-cehennem vb. kavramlar, insandaki sorumluluk bilincini kamçllayarak onun kendine gelmesini sağlamaya yönelik bir işlev gördüğünden, dünya hayatı açısından da değerli ve bir o kadar da anlamlıdır.

Öte dünya fikrine bir geçiş mesabesinde olan ve Kur'ân'da saat, ecel, va‘d kavramlarıyla ifade edilen "ölüm vakti"nin gizli tutulması, ${ }^{99}$ ölüm ve ötesini çok boyutlu bir şekilde düşünmeye sevk ederek insandaki görev ve sorumluluk bilincini katlar. $\mathrm{Bu}$ belirsizlik/muğlaklık, kişinin baskı altında kalmadan özgürce kararlarını vermesine duyulan saygının bir nişanesi ve bir samimiyet testi olarak da görülebilir. Ancak bu özgürlüğün sınırsız ve kayıtsız olmadığı, aksine sonradan mutlaka hesabını vereceği "insanın bir imtihanı" olduğu hakikatinin de ıskalanmaması gerekir. İnsanın kıyameti olan ölümün ansızın geleceğini bildiren ayetler ${ }^{100}$ de bu minvalde değerlendirilmelidir. $\mathrm{O}$ an geldiğinde herkes yapmış olduklarının hesabını verecek, ${ }^{101}$ yaptıklarına bir karşılık olarak ya cennetle mükâfatlandırılacak ${ }^{102}$ ya da cehennemle cezalandırılacaktır. ${ }^{103}$ "O halde herkes yarına ne hazırladığına baksın."104 O gün, "ahiret kazancını isteyenin kazancı arttırılacak, dünya kazancını isteyene de bu isteği verilecektir", ${ }^{105}$ dolayısıyla kişi "yaptıklarından başkasıyla cezalandırılmayacaktır."106 Son tahlilde bir imtihan alanı olan dünya,107 ahireti ve kazandırdığı ahlâkî değerleri dikkate almayanlar için "ancak bir aldanmadan ibarettir."108

Ahiret hayatıyla alakalı ayet ve kavramlar, insanın özgürlügünü kısıtlayıcı birer engel olarak görülse de son tahlilde bunlara inanmak ya da inanmamak, hayata geçirmek ya da görmezden gelmek insanın hür seçimine bırakıldığından burada gerçek anlamda bir zorlamadan bahsedilemez. Ahiretsiz bir dünyanın insan hak ve özgürlüklerini garanti altına alabileceğine yönelik düşüncelerin de sağlam bir zemine oturduğu söylenemez. Aksine ahiret hayatının varlığı ve hesap sorulabilirlik, bizzat kişi hak ve özgürlüklerini muhafaza etmek, ihlalleri en aza indirgemek içindir. Ahirete iman ilkesi, kendi özgürlük alanlarına saygı duyulmasını bir hak olarak istemek kadar başkalarının özgürlük alanlarına saygı göstermeyi de bir davranış ilkesi olarak insanın önüne koyar. Kişinin hakları onun özgürlük alanlarıdır ve bu alan başkasının hakkının başladığı yerde biter. Bir biriyle çatışmadan, uyum ve barış içinde olan özgürlüklerin yaşayabilmesi için bazı özgürlüklerin kısıtlanması bir hak ihlali değil, hakkın bizzat kendisidir. Ahiret inancı, özgürlükleri eksiksiz biçimde koruma altına alan ve yaşatan bu sınırlamanın (sorumluluk-adalet) adıdır.

\footnotetext{
99 "Saat (Kıyamet) mutlaka gelecektir. Herkes işlediğinin karşılığını görsün diye, neredeyse onu gizleyecek (geleceğinden hiç söz etmeyecek) tim.” (Tâhâ 20/15). Krş. Loḳmân 31/34; el-Mü’mîn 40/59; Fussilet 41/47; ez-Zuhruf 43/85; en-Nâzi'ât 79/42-44.

${ }^{100}$ Bk.el-A'râf 7/187; Muhammed 47/18; el-En'âm 6/31; Yûsuf 12/107; en-Nahl 16/77; el-Enbiyâ 21/40.

${ }^{101}$ Bk. en-Nisâ 4/77; el-Enbiyâ21/47; Yâsîn 36/54.

102 Bk. el-Bakara 2/82; en-Nisâ 4/124; Hûd 11/23; es-Secde 32/19.

${ }^{103}$ Bk. Tâhâ 20/74; el-Fecr 89/23; es-Secde 32/20.

${ }^{104}$ Bk. Haşr 59/18.

105 Bk. eş-Şûrâ 42/20.

106 es-Saffat 37/39.

107 Bk. el-Bakara 2/155, 214; Âl-i İmrân 3/186; el-Kehf 18/7; el-Enbiyâ 21/35; el-Ankebût 29/2-3; Muhammed 47/31; el-Mülk 67/2; el-İnsân76/2.

${ }^{108} \mathrm{Bk}$. Hadîd 57/20. Dünya hayatının oyun, eğlence ve süs olduğunu bildiren diğer ayetler için bk. Âl-i İmrân 3/185; el-En‘âm 6/32; el-Ankebût 29/64el-Hadîd 57/20.
} 


\subsection{Kader ve Kazaya İman ve Sorumlu Özgür Kişilik}

Kader ve kaza, insanın hür olup olmadığı, dolayısıyla insana gerçek anlamda eylemin nispet edilip edilemeyeceği, hür ise bu hürriyetinin dayanağının ne olduğu, zaman içerisinde yapmış olduğu eylemlerin ezelî ilim, irade ve kudretle şekillenen kaderde nasıl ve ne şekilde yer aldığı gibi sorulara cevap bulunmaya çalışılan alandır denebilir. ${ }^{109}$ Kadere iman aslında insanın, kendi hürriyet, dolayısıyla da sorumluluk alanının (ihtiyarı) dışında, insan kudret ve iradesini aşan İlâhî eylemlerin, belli bir ölçü (kanuna) dahilinde gerçekleşebileceğine inanmasıdır. Kader veya kadr kelimeleri, sözlükte miktar, ölçü, bir şeyi bir ölçüye göre tayin ve tahsis etmek, bir hikmete göre yapmak anlamlarına gelmektedir. ${ }^{110}$ Kader kelimesi Kur'ân'da bir ölçü dâhilinde tayin etmek, her şeyi bir ölçü ve nizama göre tanzim edip, tedbirlemektir. Allah'ın yaptığ 1 işlerin, yarattığı nesnelerin bir hikmete göre yapıldıklarını ifade eder ve kâinatta düzensizlik, nizamsızlık bulunmadığını ve hiçbir şeyin kendi kendine, tesadüfen var olmadığını bildirir. Allah'ın sübûtî sıfatlarıyla ilgili ve onun devamı mahiyetindeki bir konu olan kaderin, Sünnet-i İlahiyye'nin başka bir ifade şekli olduğu da söylenmiştir. ${ }^{111}$

Kader konusundaki tartışmalarda öne çıkarılan Kur'an ayetlerinin bazılarında özne olarak Allah'ın, bazılarında insanın failliğinin, bir kısmında ise insanın irade ve talebine bağlı olarak Allah'ın failliğinin vurgulandığı görülür. ${ }^{112}$ İnsana irade hürriyeti veren ayetler insanın neleri yapabileceğini gösterirken, insandan iradeyi kaldıran ayetler, insan gücünün sınırını tayin etmektedir. Kur'ân, bir yandan insanların iradeleri olduğunu, (belli sınırlar içinde) istediklerini yapabileceklerini ve daha önce onları belirli şeyleri işlemeye zorla sürükleyen bir yazgı olmadığını ifade ederken, bir yandan da her an Allah'ın irade ve kudretinin kontrolünde olduklarını, her an Allah'ın müdahale edebileceğini ve bu müdahalenin keyfiyetine göre de insandan sorumluluğun kalkacağını bildirmiştir.113

Kader meselesinde, insanın irade ve kudreti dolayısıyla da sorumluluğundaki eylemlerle bunların dışındakileri bir birinden net çizgilerle ayırmak önemli olmakla birlikte, iç içe geçişliliğin söz konusu olmasından dolayı oldukça güçtür. Sınırlı, noksan ve kendini kuşatan hemen her şeyden etkilenir bir yapıya sahip olan insanın, sınırsız ve mükemmel sıfatlarla muttasıf bir Tanrı'nın fillerini kavramasının ve kendi irade ve kudretinin sınırlarını net bir şekilde tayin etmesinin zorluğu açıtır. Ancak, insanın sorumluluğunda olup onun tercihleriyle şekillenen değişken alanla, sorumluluk alanının dışında olan değişmez yasaların (kader) hüküm sürdüğü alanın belli bir ölçüye kadar bilinmesinin konunun anlaşılmasını kolaylaştıracağı da muhakkaktır. Zira insandan beklenen, gücünün sınırlarını aşması değil, bu sınırları bilmesi ve bu sınırlar içinde imkânlarını zorlayarak sorumluluk üstlenmesidir.

\footnotetext{
109 Ahmet Saim Kılavuz, Anahatlarlyla İslâm Akâidi ve Kelâm'a Giriş, 15. Baskı, (İstanbul: Ensar Yayınları, 2010), 151.

110 İbn Manzûr, Lisânu'l-'Arab, 5: 75-78; Râğıb el-İsfehânî, el-Müfredât, 403; Âsım Efendi, Kāmmus Tercümesi, 2: 618 .

111 Bk. Atay, Kur'an'da Iman Esaslart ve Kader Sorunu, 141. Sünnetullah'1 hakkaniyet üzere işleyen yasalar olarak değerlendirmek de mümkündür.

$112 \mathrm{Bu}$ ayetlerden bazıları için bk. el-Bakara 2/82, 134, 286; en-Nisâ 4/46, 78, 155; el-Mâide 5/41; elEn'âm 6/25; Yûnus 11/74, 108; el-İsrâ 17/97; Fussilet 41/46; el-Müddessir 74/38; et-Tekvîr 81/29; elLeyl 92/5-10.

113 Bk. Atay, Kur'an'da İman Esaslart ve Kader Sorunu, 149-150; Şaban Ali Düzgün, "Kaderi Farklı Kategoriler İçinde Okumanın İmkânı”, Kelam Araştırmaları Dergisi 11/2 (2013): 7-8.
} 
Bütün varlıkların tabi olduğu, kesin ve değişmez ${ }^{114}$ varoluş kanunları vardır ki bunlarda Allah'ın varlıklara ilişkin bilgisi/ilmi belirleyicidir. Bütün varoluşlar, varlığın yapısına yerleştirilen bu kanunlara/belirlenmişliklere göre varlık alanına çıkarlar. Kur'an bu temel varoluş yasalarına, kader/takdir/mikdar gibi terimlerle işaret etmektedir. Allah'ın onları bildiği ve belirlediği şekilde cereyan eden bu kanunlar; varlık kanunları (fitratullah/âdetullah), sosyal kanunlar (sünnetullah), ahlak kanunları (sıb̆̆atullah) gibi Allah'a izafe edilen, sünnet, fitrat, âdet, sib̆ga vb. varlık tarzlarıdır. ${ }^{115}$ Buradan hareketle, en genel anlamda, insanın herhangi bir dahli olmadan hazır bulduğu, kader/takdir olarak adlandırılabilecek verili iki yapıdan söz etmek mümkündür: Bunlardan biri insanın verili/fitrî/ontik yapısı, diğeri ise gözlemleyip kararlarına dayanak yaptığı dış dünyanın verili/ontolojik yapısıdır. İnsan hazır bulduğu bu iki yapı üzerinden idrak etmekte, düşünceler geliştirmekte, muhakemelerde bulunmakta ve sonuçlara ulaşmaktadır. Bu andan itibaren insanın iradesi, seçimleri, kararları öne çıkmaya başlamakta ve sorumluluk alanının çizgileri netleşmektedir. İlahî iradeye uygun olarak doğru kararların verilebilmesi, bu iki alan arasında bir uyum ve örtüşmenin varlığıyla mümkün hale gelebilmektedir.116

Yukarıdaki ifadelerden insanın yapıp edeceklerinin kendisini mecbur birakacak tarzda (cebr) belirlendiği sonucu çıkarılmamalıdır. Belirlenmiş olan, varlıkların ve eylemlerin sıfat halleridir. Bu sifatların varlıklarla birleşme anı ya da hâli ise henüz belirlenmemiştir. Ebu Hanife bu durumu Levh-i mahfuz'dan hareketle şu şekilde açıklar: "Allah'ın dilemesi, ilmi, kazası, takdiri ve Levh-i mahfuz' daki yazısı olmadan, dünya ve ahirette hiçbir şey gerçekleşmez. Ancak O’nun Levh-i mahfuz'daki yazısı, hüküm olarak değil, vasıfladır." 117 Dolayısıyla insan, yapısı itibariyle verili/matbû' dur ama iradesi itibariyle mecbûr değildir. Başka bir ifadeyle: matbû' bir yapıya bağlı olarak ama mecbur olmadan düşünmek ve eylemde bulunmak, insanın kaderidir. ${ }^{118}$

İnsanın özgür bir iradeye ve eylemde bulunma kudretine sahip olduğu ve bunun sonucunda da yaptıklarından sorumlu tutulduğu açıktır. ${ }^{119}$ İnsan fiillerinin ihtiyarî ve 1ztırârî (zorunlu/refleksif) olarak ayrılmasının ve sevap ve cezanın ihtiyarî fiillere karşılık alınmasının, insanın bir iradeye sahip olduğunun ve bu iradesinin fiilleri işlemesinde etkin olduğunun göstergesi olduğunu Cebriyye hariç hemen hemen bütün İslam firkaları kabul etmiştir. Ebû Hanife el-Fıkhu'l-ekber'de Allah'ın kullarından hiç birini iman ve küfre zorlamadığını, onları mü'min veya kâfir olarak yaratmadığını, onları şahıslar olarak yaratıp iman ve küfrün kulların fiilleri olduğunu söyler: "Kâfir olan kendi fiili ve neticesinde Allah'ın yardımını kesmesiyle küfre sapmış, iman eden

\footnotetext{
114 “Allah'ın kanun olarak belirlediklerinde bir değişme olmaz.” Bk. el-Ahzâb 33/62; el-Fâtır 35/43; elFetih 48/23.

115 Düzgün, "Kaderi Farklı Kategoriler İçinde Okumanın İmkânı”, 2.

116 Düzgün, “Kaderi Farklı Kategoriler İçinde Okumanın İmkânı”, 4-5; Ayrıca bk. Atay, Kur'an'da İman Esaslarl ve Kader Sorunu, 143, 145, 149.

117 Ebû Hanîfe, el-Fıkhu'l-ekber (İmâm-ı Azamın Beş Eseri içinde), trc. Mustafa Öz, (İstabul: Kalem Yayıncılık, 1981), 67; Krş. Ali el-Kârî el-Herevî, Şerhu'l-Fıkhi'l-ekber, (Mısır: y.y., 1323), 36.

118 Düzgün, "Kaderi Farklı Kategoriler İçinde Okumanın İmkânı”, 5.

119 Leyl Suresi 92/5-10 ayetleri, el-İsrâ 17/13 ve en-Necm 53/39-41 sikıntıya uğrama yahut rahata kavuşmayı kulun amellerine bağlar. Konuyla ilgili diğer ayetler ve açıklamaları için bk. Lütfi DoğanYaşar Kutluay "Hasan Basrî’nin Kader Hakkında Halife Abdülmelik b. Mervan’a Mektubu”, Ankara Üniversitesi Ilahiyat Fakültesi Dergisi 3/3 (1954): 75-84; Michael Schwarz (Hayfa), "Hasan Basrî'nin Kader Risalesi Üzerine Bir İnceleme", trc. Muhit Mert, Gazi Üniversitesi Çorum İlahiyat Fakültesi Dergisi 2/3 (2003): 123-141.
} 
de kendi fiili ve Allah'ın yardımıyla iman etmiştir" der. ${ }^{120}$ İnsanın bütün yapıp etmelerinin daha önceden yazılı olduğunu delillendirmek amacıyla öne sürülen er-Ra'd 13/39 ayeti şöyle demektedir: "Allah dilediğini siler, dilediğini de sabit k1lıp bırakır. Ana kitap (Ümmü'l-Kitâb) O'nun yanındadır." Allah'ın belli bir hikmete/kanuna mebni olarak silmesi ve sabit bırakması, yani Ümmü'l-Kitâb'ta (Levh-i Mahfûz) Allah'ın iradesine bağlı olarak bir değişikliğin meydana gelmesi aslında sabit, değişmez bir yazgının olmadığının önemli delillerindendir. Kişinin yaşamında pişmanlıkların ve 'keşkeler'in olması, başkalarını hata, kusur ve suçlarından dolayı kınaması ve onlardan sorumluluk üstlenmelerini beklemesi de bu kanıtlardandır.

Kişinin irâdî fiillerinin meydana gelmesinde önemli katkısı olduğunun bilincinde olması, irade ve kasdı olmadan eylemlerinin çoğunun gerçekleşmeyeceğini bilmesi yapıp etmelerinde daha bilinçlice hareket etmesini, kararlarını verirken daha dikkatli davranmasını sağlayacaktır. Kadere iman ilkesi, inananların sorumluluk bilinciyle gerçekleştirecekleri hür atılımlarına engel teşkil edecek şevk kırıklı̆̆l, ümitsizlik ve haddi aşma gibi olumsuzlukların baş göstermesine firsat vermez. "Kadere iman eden, kederden emin olur" sözünde belirtildiği gibi, sınırlı varlığın kontrol altına alabileceği şeyler de imkânı oranında sınırlı olacağından, bu ilke inanan için önemli bir teselli kaynağıdır. Burada inanandan beklenen, neticeye mutlak surette ulaşması değil, yeteneklerini ve imkânlarını son raddesine kadar kullanma başarısını göstermesidir. Geleceğini belirlemede hiçbir tesirinin olmadığına inanmak (cebr) ise kişiyi ümitsizliğe, pasifize ederek atıl hale getirdiği benliğini yavaş yavaş tüketmesine ve eylemlerinin öznesi iken nesnesi olmaya sevk edecektir.

Hz. Âdem'in ilk itaatsizliği, insanoğlunda ilk özbenlik şuurunun bir işareti, hürriyetin bir nişânesi olarak da görülebilir. Eğer insanın böyle bir hürriyeti olmasaydı ahlâkî anlamda onun bir değeri de olmayacaktı. İnsan için hürriyet onun iyiliklerde bulunmasının ilk ve en önemli koşuludur. Kişi, iyiyi seçip kötülüklerden mümkün mertebe kaçtıkça kendini geliştirir, potansiyellerinin farkına varır ve daha iyiye doğru sürekli bir eğilim gösterir. Bilerek ya da bilmeyerek yaptığı kötülüklerin sonuçlarının ders verici, tecrübe kazandırıcı niteliği onun tekâmülü için bir basamak niteliğindedir. Nitekim Hz. Âdem ilkin yanlış kullandığı hürriyetini pişmanlık ve halisane tövbe ile ${ }^{121}$ hayra kanalize ederek af kapısını aralamıştır. Yapılan her iyilik ve kaçınılan ya da engellenen her kötülük kişiyi olgunlaştırdığı gibi toplum içerisinde ma'rûf ahlakının yayılmasına da katkı sunacaktır. Kaçınılamayacak, hesapta olmayan kötülüklerle karşılaşılması durumunda sabır ve daha da kötüsüne uğramamaktan dolayı duyulan şükür duygularını geliştirecektir. Tevekkül, sabır, şükür, tövbe ve bunların tamamını içeren dua gibi değiştirici ve dönüştürücü kavramlar, imkânlarını (istitaat) aşan durumlarda dahi insanın belli düzeyde de olsa hürriyetinin olduğunu ve dolayısıyla da sorumluluk yüklenebileceğini göstermesi açısından önemlidir. Böylece Sonlu Benin genişleyen ve zenginleşen hayatı, çabalarla ve yanılmalarla yoluna devam edecektir. ${ }^{122}$

Kur'ân'da kadere imanın bu yönüne dikkat çeken el-Hadîd 22. ayet şunları söyler: "Yeryüzünde ve kendi nefislerinizde uğradığınız hiçbir musibet yoktur ki, biz onu yaratmadan önce, bir kitapta (Levh-i Mahfuz) yazılmış olmasın. Şüphesiz bu Allah'a göre kolaydır." Ayetin devamında ise Allah bir önceki cümleyi, inananların ümitsizliğe

\footnotetext{
${ }^{120}$ Ebû Hanîfe, el-Flkhu'l-ekber, 68.

${ }^{121}$ Bk. el-Bakara 2/37; el-A'râf 7/23.

122 Bk. Muhammed İkbâl, İslâm'da Din̂̂ Tefekkürün Yeniden Teşekkülü, trc. Sofi Hûrî, (İstanbul: Kırkambar Yayınları, 1999), 102.
} 
düşmemeleri ve haddi aşıp böbürlenmemeleri için sarf ettiğini açık bir şekilde dile getirir: 'Elinizden çıkana üzülmeyesiniz ve Allah'ın size verdiği nimetlerle şımarmayasınız diye (böyle yaptık). Çünkü Allah, kendini beğenip övünen hiç kimseyi sevmez" (el-Hadîd 57/23) Benzer bir ayet de şu şekildedir: "De ki: 'Bizim başımıza ancak Allah'ın bizim için yazdığı şeyler gelir. O bizim yardımcımızdır. Öyleyse mü'minler yalnı Allah'a güvensinler"' (et-Tevbe 9/51) Bu ayette de Allah, Peygamber'e teselli vermek ve mü'minlerin azimlerinin kırılmasının ve ümitsizliğe düşmelerinin önüne geçmek istemiştir. Bu gibi felaketlerin yazılı ilahi kanunlara uygun olduğu bildirilerek mü'minlere teselli verilmiş, başlarına bir felaket geldiğinde maneviyatlarının kuvvetlenmesi için bazı başarısızlıkların olabileceği ancak, Allah katındaki derecelerinin baki kalacağı hatırlatılmak istenmiştir: "De ki: Bizim için siz ancak (zafer ya da şehitlik gibi) iki güzellikten birini bekleyebilirsiniz” (et-Tevbe 9/52)

Kur'ân'da insan fiillerinden bahsedilirken hem Allah'ın yaratıcılığından (halk) ${ }^{123}$ hem de kulun yapıcılığından (kesb) söz edilir. ${ }^{124}$ Bütün bunların insanın maddî ve manevî hayatından bağımsız, yani onu etkilemeden ve hiçbir tesire uğratmadan geliştiğini söylemek de yanlış olur. Dolayısıyla, keskin hatlarla bir ayrışmadan ziyade bir iç içe geçmenin varlığından bahsetmek daha isabetli olacaktır. Sonuç olarak, insan ne cebr altındadır ne de sınırsız, mutlak bir özgürlüğe sahiptir. Kudret ve iradesini aşan durumlarda, olaylara Allah'ın yaratması cihetiyle bakarak, O'nun hikmet, adalet ve merhamet gibi sıfatlarına sığınarak bir teselli ve huzur bulur, sükûnete erer. O'nun azameti karşısında acziyetini ve sınırlarını fark ederek, her istediğini elde edemeyeceğini anlar, ${ }^{125}$ kibir ve onun yol açtığı tanrılaşma temayülünden uzak durur. Haddini bilir; kendi yaradılışına ve yaratılmış olan her şeye karşı hadsizlik yapmaktan kendini alıkoyar. İnsana düşen kesb cihetiyle baktığında ise sorumluluk üstlenir, daha iyiyi elde etmek üzere bir çaba içine girer. ${ }^{126}$

\section{SONUÇ}

'Aḳīde ve iman kavramları zorlama ve baskıyı kabul etmeyen gönülden, samimi ve sağlam bir bağlılığın yanında, Allah'la bir akidleşme ve sözleşmeyi ve bu sözleşmenin gereklerini yerine getirmeye yönelik sorumluluğu ifade eden iki önemli kavramdır. Her iki kelimenin anlam haritasını özgürlük ve sorumluluk oluşturduğundan özgürlük ya da sorumluluk hissinden herhangi birinin eksik olduğu bir iman anlamlı olmayacaktır. Sorumlulukların yerine getirilebilmesi için özgürlük; özgürlüğün anlam kazabilmesi için de sorumluluk/sınırlama şarttır. Özgürlük ve sorumluluk, zıd gibi görünseler de birbirini var ve anlamlı kılmaktadır.

'Aḳāid olarak da isimlendirilen iman esasları, sadece iman edilip geçilen birer ilkeler manzumesinden; 'aḳāid metinleri de dogmatik birer metinden ibaret değildir. O her şeyden önce ahlaki bir toplum oluşturmaya yönelik Kur'ânî hedefi gerçekleştirecek

\footnotetext{
$123 \mathrm{Bu}$ kavramın insan için de kullanılabileceğine dair bir çalışma için bk. Erkan Yar, “Allah'ın İsimlerinin İnsanın Kişilik Gelişimine Etkisi”, 163-182.

${ }^{124}$ Bk. Mâtürîdî, Kitâbü't-Tevhîd, 228; Nesefî, Tebșıratü'l-edille, 2: 641; Teftâzânî, Kelâm İlmi ve İslam Akâidi, (Şerḥu'l- 'Aķāidd), hzr. Süleyman Uludağ, (İstanbul: Dergâh Yayınları, 1982), 200. Ayrıca fiillerin insana bakan ve sorumluluk gerektiren yönü anlamındaki kesb için bk. el-Bakara 2/79, 81, 134, 141, 202, 225, 264, 267, 281, 286; el-En'âm 6/121; el-A'râf 7/96; et-Tevbe 9/82, 95; Yûnus 10/8; el-Hicr 15/84; Yâsin 36/65; ez-Zümer 39/50; Fussilet 41/17; el-Câsiye 45/14; el-Mutaffifîn 83/14.

${ }^{125} \mathrm{Bk}$. "Yoksa insan her istediğini elde edeceğini mi zanneder" (en-Necm 53/24)

${ }^{126}$ Bk. "Herkes kazandığına karşılık bir rehindir" (el-Müddessir, 74/38); Krş. en-Necm 53/39.
} 
model bir kişilik inşasına yönelir. İmanın kalbî ve irâdî bir eylem olması ve cebri dışlaması bütün iman esaslarına sirayet eden temel bir unsurdur. İnanandan beklenen, özgür kararıyla bu esasları benimsemesi ve bu imanın gereklerini yerine getirme konusunda sorumluluk üstlenmesidir. Söz konusu sorumluluklar inananın elinden özgürlüğünü alan birer kısıtlayıcı ya da engelleyici unsur değil; bizzat bu özgürlüğü koruma altına alan, anlamlı ve var kılan bariyerler hükmündedir. Zira sınırsızlık, özgürlüğü ortadan kaldıran bir kaos halidir ve özgürlüğün tam olarak anlamını bulması için belli sınırlılıklara ihtiyaç vardır. Özgür bir kararın eseri olan imanı anlamlı kılan da bu sınır ve sorumluluklardır. İman esasları özgürleştirici ve sorumlu kılıcı yönüyle tek tek bu bilince sahip ve onu hayatın her alanına taşıyacak özgür ve sorumlu aktif kişilikler yetiştirmeyi bir hedef olarak insanlığın önüne koyar.

İman esaslarının ilki olan “zat ve sıfatlarıyla birlikte, Allah'ın varlığına ve birliğine iman”, Allah'ı ve tevhid inancını tanıyıp anlamayı ve bunun gereklerini yerine getirmeyi içerir. Buna göre Allah, tüm kâinatı yaratan, insanı var eden, dünyayı imar etmesi için insanoğluna sorumluluk yükleyen, bu sorumluluk gereği iyiyi ve kötüyü seçme şansı vererek onu özgür kılan, özgür iradesiyle yaptığı seçimlerinin bir sonucu olarak ahirette insana ödül veya ceza verecek olan, her şeyi gözetleyen yaratıcıdır. Dolayısıyla bu ilke, Yaratıcısının karşısında hem sorumlu hem de özgür kılınan bir 'abd portresi çizmektedir. Tevhid ilkesi de diğer itaat türlerini reddederek sadece Yaratıcısı'na kulluk eden ve kendini diğer bütün şeylerin (mâ sivallah) boyunduruğundan kurtararak özgürleştiren bir kişiliği öne çıkarır. Bu inancı içselleştiren kişilik, bir ırka, dine, bir cemaate ya da bir ekole yani isimlere aidiyetin değil, Allah'ın tüm insanlara önerdiği Tevhid akidesine uygun olarak yapılan salih amellerin değerli olduğunun, dünya ve ahiret saadetini kazanmak için sadece inanmanın yetmediğinin, vahye göre yaşamanın da önemli olduğunun yani sorumluluklarının da bilincinde olan kişiliktir.

Peygamberler ve ilahî kitaplar, bir yandan sun'î bağlardan kurtarmak suretiyle insanlara özgürlüklerini verirken, diğer yandan da durmaları gereken sınırları göstererek sorumluluklarına göndermede bulunmuştur. $\mathrm{Bu}$ durum inananın hem özgür hem de özgürleştiren aynı zamanda da sorumluluklarının bilincinde olarak yaşamına yön veren bir kişilik sergilemesi gerektiğini vurgulamaktadır.

Meleklere inanmak, aradaki ontolojik farklılıklara ragmen, melekleri modelleyerek hayra ve iyiliğe yönelmeyi, şerri işlemekten kaçınmayı ve şerrin işlenmesine de güç (istitaat) oranında engel olmayı ilke edinmeyi gerektirir. Meleklerin insanları hayra yönlendirirken ve şerden uzaklaştırırken baskıcı olmayan ancak bir karşılığın mutlaka olacağını ihsas edici yöntemleri, "iyiliği emr ve kötülükten men” ilkesini uygulayacak mü'min için bir örneklik teşkil eder. Hem meleklere iman hem de ahiret gününe iman, insan fiillerine müdahale edilmeksizin her şeyin kayıt altına alındığını ve karşılığının mutlaka verileceğini deklare eder. Bu durumda insan, hayrı da şerri de seçme özgürlüğüne sahip olmakla birlikte, varlıklar kategorisinde kendisine verilen seçkin konum ve ayrıcalıklı yeteneklerinden dolayı içinde yaşadığı evrende hayrı yaymak ve sürekli hale getirmekle mükelleftir. $\mathrm{Bu}$ yükümlülükler onun özgürlügünü elinden almamakta aksine garanti ve koruma altına almaktadır. Mutlak adaletin gerçekleşeceği bir ahiret tasavvuru, ona en yakın adalet düşüncesinin yeryüzünde de gerçekleştirilmesine yönelik özgür bireyleri sorumluluğa davet eder.

Allah'ın ilim, irade, kudret ve (Mâtürîdîler'e göre) tekvin sıfatlarıyla ilintili olan "Kadere iman" esası da inanç sahiplerine, Allah'ın her şeyi insan fitratıyla uyumlu şekilde bir ölçü ve nizam içinde yarattığını, insanın bu nizamı sürdürmedeki başarısının kendi kaderini belirlediğini ve sadece iradesiyle bilinçli bir şekilde yaptıklarından 
sorumlu olacağını "kişi kazandıklarına karşılık bir rehindir" (et-Tûr 52/21; el-Müddessir 74/38) ayeti gereğince öğretir. Böylece o, Allah'a bakan yönüyle, insan iradesini ve imkânlarını aşan olaylarda kişiyi sorumluluk ve dolayısıyla acı, 1stırap ve kaygı yüklerinden kurtarıp özgürleştirirken, insana bakan yönüyle, dünyada ve ahirette huzuru elde etme imkânının kişinin elinde olduğunu (sorumluluk) imler.

Bir bütün halinde değerlendirildiğinde iman esaslarının, Allah tarafından kendisine bahşedilen halîfetü'l-arz ve eşrefu'l-mahlûkat makamına ve ismine layık model bir kişilik oluşturmayı hedeflediği görülür. Taşıyla toprağıyla kendisine emanet olarak bırakılan yeryüzü âlemini ma'mur etmesi beklenen bu kişiliğin bunu gerçekleştirebilmesi için, her koşulda adaleti ve artı değer olarak ihsanı ayakta tutması, yeryüzü işleyişinin hayra doğru evirebilmesi için elinden gelen gayreti göstermesi gerekir. Onun bu çabasını değerli kılan, iradesini iyiye doğru yönlendirebilme başarısını gösterebilmesi, özgürlügünün sorumluluğunu üstlenerek enerjisini ve yeteneklerini güzellikleri inşa etmede tüketmesidir.

\section{KAYNAKÇA}

Abdülbâkî, M. Fuad. el-Mu'cemü'l-Müfehres li-elfâzi'l-Kur'âni'l-Kerîm. Kahire: y.y., 1988.

Abdülcebbâr, Ebü'l-Hasen Kādı'l-kudât b. Ahmed b. Abdilcebbâr el-Hemedânî. elMuhtașar fì ușûli'd-dîn (Resâilu'l-'adl ve't-tevhîid içinde). Nşr. Muhammed Umâre. Kahire: Dâru'l-Hilâl, 1971.

Kādî Abdülcebbâr. Şerḥu'l-Ușûli'l-ḥamse. Thk. Abdülkerîm Osman. 3. Baskı. Kahire: Mektebetü vehbe, 1416/1996.

Alper, Hülya. "Kelâm İlminde Aklın ve Vahyin Yeri”. İslâmî İlimlerde Metedoloji/Usûl-IV. Akâid ve Kelâm Ilminde Aklın ve Vahyin Yeri- Tartışmalı İlmî İhtisas Toplantıst. 115-154. İstanbul: 20-21 Ekim 2012

Alper, Hülya. "İmam Mâturîdı̂’de Akıl-Vahiy İlişkisi: Aklın Önceliği ve Vahyin Gerekliliği”. Milel ve Nihal 7/ 2 (Mayıs-Ağustos 2010): 6-29.

Altıntaş, Ramazan. İslam Düşüncesinde İşlevsel Akıl. İstanbul: Pınar Yayınları, 2003.

Âsım Efendi. "Emn”. Kāmus Tercümesi. 4: 548-549; “aḳd”. Kāmus Tercümesi. 1: 1212-1215. İstanbul: Cemal Efendi Matbaas1, 1304-1305.

Atay, Hüseyin. İslâm'ın İnanç Esasları. Ankara: AÜİF Yayınları, 1992.

Atay, Hüseyin. Kur'an'da Iman Esaslarl ve Kader Sorunu. Ankara: Pozitif Matbaacılık, 2009.

Ateş, Süleyman. “Kur’ân-1 Kerîm’e Göre Evrim Teorisi”. Ankara Üniversitesi Illahiyat Fakültesi Dergisi 20/1 (1972): 127-146.

Ateş, Süleyman. Kur'an Ansiklopedisi. (30 cilt) İstanbul: Kuba Yayınları, 1997. 
Ay, Mahmut. “Ahirete İman”. İslâm İnanç Esasları El Kitabı. Edt. Ş. Ali Düzgün, Ankara: Grafiker Yayınları, 2013.

Ay, Mahmut. “Kelam'da Akıl İman İlişkisi: Temel Teolojik Yaklaşımlar”. Ankara Ü. Illahiyat Fakültesi Dergisi 52/1 (2011): 49-68.

Aydın, Ali Arslan. "Peygamberimiz, İman Esasları ve Tevhid Akidesi". Diyanet Dergisi Özel Sayı (1970), 56-63

Aydın, Ömer. İslam İnanç Esasları. İstanbul: İşaret Yayınları, 2012.

Bağdadî, Ebû Mansûr Abdülkāhir b. Tâhir et-Temimî. el-Fark beyne'l-firak. Nşr. M. Abdülhamid. Beyrut: y.y., 1416/1995.

Bağdâdî, Abdülkāhir. Usûlü'd-dîn. Nşr. Ahmed Şemsuddîn. Beyrut: Dâr'ül-Kütübi'l'İlmiyye, 1423/2002 ve İstanbul: y.y., 1346/1928.

Bâkıllânî, Ebû Bekr Muhammed b. Tayyib b. Muhammed el-Basrî. el-İnșâf fî mâ yecibu i 'tikāaduhu velâ yecûzu'l-cehlu bihi. Nşr. İmâduddîn Ahmed Haydar. Beyrut: 'Âlemu'lKutub, 1407/1986.

Bâk1llânî, Kitâbü Temhîdi'l-evâ'il ve't-telhîșü'd-delâ'il. Nşr. İmâdüddîn Ahmed Haydar. Beyrut: Müessesetü'l-Kütübi's-Sekâfiyye, 1414/1993.

Beyâzîzâde, Kemaleddin Ahmed. İşârâtü'l-merâm min 'ibârâti'l-İmâm. 1. Bask1. İstanbul: Daru'l-Kütübi'l-İslâmi, 1949; nşr. Yûsuf Abdürrezzâk. Kahire: y.y., $1368 / 1949$.

Bolay, Süleyman Hayri. “İman”. Felsefî Doktrinler Sözlüğü. 215-216 İstanbul: Ötüken Yayınevi, 1981.

Cevizci, Ahmet. "Olgu". Paradigma Felsefe Sözlüğü 640-641 İstanbul: Paradigma Yainevi, 1999.

Chittick, William. Varolmanın Boyutları. çev. Turan Koç. İstanbul: İnsan Yayınları, 1995.

Cürcânî, Seyid eş-Şerîf Ali b. Muhammed. "vhd”. Kitabu't-Ta 'rîfât. 1. Baskı. Beyrut: Daru'l-Kütübi'l-İlmiyye, tsz.

Cürcânî, Seyyid eş-Şerîf. Şerhü'l-Mevâkıf. (1-8) Beyrut: Dârü'l-Kütübi'l-‘İlmiyye, $1419 / 1998$.

Cüveynî, İmâmu'l-Haremeyn Ebü'l-Meâlî Rüknüddîn Abdülmelik b. Abdillâh b. Yûsuf. Kitâbu'l-irşâd ilâ kavâtı 'i'l-edille fì usûli'l-i 'tikād. Nşr. Es'ad Temîm. Beyrut: Dâru'lKutubi'l-İlmiyye, 1405/1985.

Doğan, Lütfi - Kutluay Yaşar. "Hasan Basrî’nin Kader Hakkında Halife Abdülmelik b. Mervan'a Mektubu”. Ankara Üniversitesi İlahiyat Fakültesi Dergisi 3/3 (1954): 75-84.

Düzgün, Şaban Ali. Din Birey ve Toplum. Ankara: Akçağ Yayınları, 1997. 
Düzgün, Şaban Ali. “Allah'a İman”, İslâm İnanç Esasları. Ed. Ş. Ali Düzgün, Ankara: Grafiker Yayınları, 2013.

Düzgün, Şaban Ali. "Kaderi Farklı Kategoriler İçinde Okumanın İmkânı". Kelam Araştırmaları. 11/2 (2013): 1-10.

Ebû Hanîfe, Nu'mân b. Sâbit b. Zûtâ b. Mâh. el-Fikhu'l-ekber. (Ali el-Karî, Serhuu'lFıkhi'l-ekber içinde). Beyrut: y.y., 1404/1984; (İmâm-ı Azamın Beş Eseri içinde). Trc. Mustafa Öz. İstabul: Kalem Yayınc1lı, 1981.

Erdemci, Cemalettin. "Kelâm İlminde Akıl ve Naklin Etkinliği Problemi", Kelâm İlmi'nin Yeniden İnşasında Geleneğin Yeri Koordinasyon Toplantısı ve Sempozyum Bildirileri. 329-340. Elazığ: Fırat Üniversitesi İlahiyat Fakültesi, 2004.

Eş'arî, Ebü'l-Hasen Alî b. İsmâîl b. Ebî Bişr İshâk b. Sâlim. Kitâbü'l-Luma 'fi'r-red 'alâ ehli'z-zeyg ve'l-bida'. nşr. Abdulazîz İzzu'd-Dîn es-Sirvânî. Birinci Baskı Beyrut: Daru'l-Lübnan, 1987.

Faruki, İsmail Raci. Tevhid. Trc. Dilaver Yardım-Latif Boyacı. İstanbul: İnsan Yayınları, İstanbul 1995.

Fatiş, Emrullah. "Meleklerde Şuur ve İrade Problemi". Kelâm Araştırmaları Dergisi 13/2, (2015): 785-806.

Gazzâlî, Ebû Hâmid Muhammed b. Muhammed. el-ị̧̧tișâd fi'l-i 'tiķāad. Nşr. İ. Agâh Çubukçu-Hüseyin Atay. Ankara: y.y., 1962.

Gazzâlî, Ebû Hâmid. İtikad'da Orta Yol. Trc. Kemal Işık. Ankara: Ankara Üniversitesi İlahiyat Fakültesi Yayınları, 1971.

Görmez, Mehmet. “İnsanlığı Yaşatmak İçin Gelin Birlik Olalım”. Hz. Peygamber, Tevhid ve Vahdet. 7-11. Ankara: DİB Yayınları, 2016.

Güler, İlhami. İman Ahlâk İlişkisi. Ankara: Ankara Okulu Yayınları, 2003.

Güler, İlhami. "İman ve İnkârın Ahlâkî ve Bilişsel (Kognitif) Temelleri". İslâmiyât 1/1 (Ocak-Mart 1998): 7-24.

Harputî, Abdüllatîf. Tenkîhu'l-kelâm fì 'akâidi ehli’l-İslâm. İstanbul: Marmara Üniversitesi İlahiyat Fakültesi Kütüphanesi, Necmu İstikbal Matbaası, 1327.

İbn Ebi'l-İzz, Sadruddîn Ali İbn Muhammed el-Hanefî. Şerḥu't-Tahâviyye fìl'akîdeti's-Selefiyye.. Thk. Ahmed Ali, Kahire: Dâru'l-Hadîs, 2005.

İbn Hazm, Ebû Muhammed Alî b. Ahmed b. Hazm el-Endelüsî. el-Faṣl fi'l-milel ve 'lehvâ' ve'n-niḩal. Nşr. Muhammed İbrâhim Nasr-Abdurrahmân Umeyre. Beyrut: Dârü'l-Cîl, ts.

İbn Kayyim el-Cevziye. Medâricü's-Sâlikîn. Nşr. Abdu'l-Mün'im Salih Ali el-İzzî. 2. Bask1. b.y.: Müessesetu'r-Risâle, 1986. 
İbn Manzûr, Ebu'l-Fazl Muhammed b. Mukrim el-Efrikî, Lisânu'l-'Arab, Beyrut 1955/1970.

İbn Rüşd, Ebu'l-Velîd Muhammed b. Ahmed b. Muhammed. el-Keşf. Nşr. Mustafa Abdülcevâd İmrânî. Kahire: y.y., 1388/1968.

İkbâl, Muhammed. İslâm'da Dinî Tefekkürün Yeniden Teşekkülü. Trc. Sofi Hûrî, İstanbul: Kırkambar Yayınları, 1999.

İsfehânî, Ebü'l-Kāsım Hüseyn b. Muhammed b. el-Mufaddal er-Râgıb. "Emn". elMüfredât fì garîbi'l-Ķur'ân. İstanbul: Kahraman Yayınları, 1986; Mısır: Meymeniyye Matbaas1, 1324.

İzmirli, İsmail Hakkı. Yeni İlmi Kelam. Haz. Sabri Hizmetli. Ankara: Umran Yayınları, 1981.

Karakuşçu, M. Nail. Genel Psikoloji ve Normal Davranışlar. Ankara: Çelik Yayınları, 1988.

Kılavuz, Ahmet Saim. “Akaid”. Türkiye Diyanet Vakfi İslâm Ansiklopedisi 2: 212-216. Ankara: TDV Yayınları, 1989.

Kılavuz, Ahmet Saim. Anahatlartyla İslâm Akâidi ve Kelâm'a Giriş. İstanbul: Ensar Yayınları, 2010.

Kılıç, Recep. Modern Batı Düşüncesinde Vahiy. İstanbul: Ötüken Yayınları, 2004.

Makrîzî, Takiyuddîn Ahmed b. Ali b. Abdilkâdir b. Muhammed. Tecrîdu't-Tevhîdi'lMüfíd. Nşr. Ahmed b. Muhammed Tâhûn. Kahire: Mektebetu't-Turâsi'l-İslâmî, 1414/1993.

Mâtürîdî, Ebû Mansûr Muhammed b. Muhammed b. Mahmûd es-Semerkandî. Kitâbü'tTevhîd. Nşr. Bekir Topaloğlu- Muhammed Aruçi, Ankara: Türkiye Diyanet Vakfı Yayınları, 2003.

Mâtürîdî, Ebû Mansûr Muhammed. Kitabu't-Tevhid. Trcm. Bekir Topaloğlu. Ankara: Türkiye Diyanet Vakfı Yayınları, 2002.

Mâtürîdî, Ebû Mansûr Muhammed. Te’vîlâtü'l-Kur'ân. İlmî Kontrol: Bekir Topaloğlu. (I-XVII) İstanbul: Mizan Yayınevi, 2005-2010.

Mehmedoğlu, Yurdagül. "0-6 Yaş Çocuğunun Dini Duygu Gelişimi". Evin Okula Yakınlaşması ve Değişen Anne-Baba Rolleri. 109-131. Ankara: MEB Yayınları, 2003.

Mevdûdî, Ebu'l-Alâ. Tefhîmu'l-Kur'ân. Trc. Komisyon. İstanbul: İnsan Yayınları, 1991.

Nesefî, Ebü'l-Muîn Meymûn b. Muhammed b. Muhammed b. Mu'temid. Tebṣıratü'ledille fì uṣ̂uli'd-dîn. Thk. Hüseyin Atay, Ş. Ali Düzgün. Ankara: DİB Yayınları, 2004. 
Nesefî, Ebü'l-Muîn Meymûn b. Muhammed b. Muhammed b. Mu'temid. Kitâbu'tTemhîd li-ksavâ idi't-tevhîd. Thk. Habîbullah Hasan Ahmed. Dâru't-Misır: Tabâ'ati'lMuhammediyye, 1986/1406; Nşr. Abdulhayy Kâbil. Kahire: Dâru's- Sekâfe, 1987.

Özcan, Hanifi, Epistemolojik Açıdan Iman, İstanbul: İfav Yayınları, 1997.

Özcan, Hanifi, Mâtûrîdı̂'de Dinî Çoğulculuk, İstanbul: M. Ü. İlahiyat Fakültesi Yayınları, 1995.

Özler, Mevlüt. “Tevhid”. Türkiye Diyanet Vakfi Íslam Ansiklopedisi. 41: 18-20. Ankara: TDV Yayınları, 2012.

Pazarl1, Osman. Din Psikoloji. İstanbul: Remzi Kitabevi, 1982.

Pezdevî, Ebu'l-Yusr Muhammed b. Hüseyin. Ehl-i Sünnet Akâidi. Trc. Şerafeddin Gölcük. İstanbul: Kayıhan Yayınları, 1980.

Sâbûnî, Ebû Muhammed Nûruddîn Ahmed b. Mahmûd b. Ebî Bekr. el-Bidâye fî uṣ̂uli'ddîn (Mâtürîdiyye Akâidi). Trc. Bekir Topaloğlu. Ankara: DİB Yayınları, 1979.

Schwarz (Hayfa), Michael. "Hasan Basrî’nin Kader Risalesi Üzerine Bir İnceleme". Trc.. Muhit Mert. Gazi Üniversitesi Çorum Illahiyat Fakültesi Dergisi 2/3 (2003): 123141.

Şahinalp, Hacer. Kur'ân'da Din Hürriyeti. Doktora Tezi, Ankara Üniversitesi, 2010.

Şaşa, Mehmet. "Kelâm Ekolleri Bağlamında Marifetullah'ın Vücûbiyet Kaynağı". Artuklu Akademi 5/1 (Haziran 2018): 57-90.

Tatar, Burhanettin. "İki Temel Kavram: Tevhid ve Vahdet". Hz. Peygamber, Tevhid ve Vahdet. 13-19. Ankara: DİB Yayınları, 2016.

Teftâzânî, Sa'düddîn Mes'ûd b. Fahriddîn Ömer b. Burhâniddîn Abdillâh el-Herevî elHorâsânî. Şerḥu’l-Maķāṣıd. İstanbul 1305.

Teftâzânî, Sa'düddîn Mes'ûd b. Fahriddîn Ömer b. Burhâniddîn Abdillâh el-Herevî elHorâsânî. Şerhư'l- 'Aķa 'id. İstanbul: Bahar Matbaası, 1973.

Teftâzânî, Sa'düddîn Mes'ûd b. Fahriddîn Ömer b. Burhâniddîn Abdillâh el-Herevî elHorâsânî. Kelâm Illmi ve İslam Akâidi, (Şerḥu'l-'Akgàid). Hzr. Süleyman Uludağ. İstanbul: Dergâh Yayınları, 1982.

Tehânevî, Muhammed A'lâ b. Alî b. Muhammed Hâmid el-Fârûkī. "emn”. Keş̧̧âfü ıștılâhâti'l-fünûn ve'l-'ulûm. Thk. Ali Dehrûc. 1. Baskı Beyrut: Mektebetü Lübnan, 1996.

Topaloğlu, Bekir-Çelebi, İlyas. Kelâm Terimleri Sözlüğü. 318-319. İstanbul: İSAM Yayınları, 2010.

Topçu, Nurettin. Ruhbilim. İstanbul: Üçler Basımevi, 1949. 
Yar, Erkan. “Allah'ın İsimlerinin İnsanın Kişilik Gelişimine Etkisi”. Uluslararası Kişilik ve Karakter İnşâsında Dinin Yeri Sempozyumu Bildirileri (Ordu, 10-12 Haziran 2016), ed. Y. Ünal, Ş. Pekdemir, Y. B. Gündoğdu, O. İyibilgin, S. Kar, 163-182 Ordu: Ordu İlahiyat Vakfı Yayınları, tsz.

Yeşilyurt, Temel. "Tevhidi Zedeleyen Söylemler”. Hz. Peygamber, Tevhid ve Vahdet. 133-141. Ankara: DİB Yayınları, 2016.

Zekeriyyâ, Ebû Bekr Muhammed. eş-Şirk fi'l ḳadîm ve'l- hadîs. Riyad: Mektebetü'rRüşd, 2005. 